by Gaoxue Yang ${ }^{a, b}$, Yildirim Dilek ${ }^{c}$

\title{
OIB- and P-type ophiolites along the Yarlung- Zangbo Suture Zone (YZSZ), Southern Tibet: Poly- Phase melt history and mantle sources of the Neotethyan oceanic lithosphere
}

\author{
${ }^{a}$ School of Earth Science and Resources, Chang'an University, Xi'an 710054, China. Corresponding author E-mail: mllygx@126.com \\ ${ }^{\mathrm{b}}$ Key Laboratory for the study of Focused Magmatism \& Giant Ore Deposits, MLR, Xi'an 710054, China \\ ${ }^{\mathrm{c}}$ Department of Geology \& Environmental Earth Science, Miami University, Oxford, OH 45056, USA. E-mail: dileky@miamioh.edu
}

DOI:10.18814/epiiugs/2015/v38i4/82420

We present an overview of the internal structure of the ophiolite massifs along the Yarlung Zangbo suture zone (YZSZ) in southern Tibet with a focus on the geochemical character and tectonic evolution of the Ocean Island Basalt (OIB) and mafic alkaline rock assemblages associated with these ophiolites. The Jurassic - early Cretaceous lavas, massive diabase and gabbroic rocks are either tectonically intercalated with the early Cretaceous, subduction-influenced ophiolitic units, or occur as thrust sheets or blocks with an early Cretaceous mélange and in a Jurassic-Cretaceous flysch unit structurally beneath these ophiolites. They display uniform chondrite-normalized REE patterns with light rare earth element (LREE) enrichment and heavy rare earth element (HREE) depletion, no obvious Eu anomalies or negative $\mathrm{Nb}, \mathrm{Ta}$ and Ti anomalies, and primitive mantle normalized trace element patterns with significant large-ion lithophile element (LILE) enrichment, similar to those of modern OIB and the Hawaiian alkaline basalts. These mafic alkaline rock assemblages represent OIB- and Plume-type (P-type) oceanic crustal rocks (with no subduction influence) that formed from magmas produced by partial melting of plume-metasomatized asthenospheric mantle source during the early stages of the opening of a Neotethyan seaway between Proto-India and Eurasia. Subsequent consumption of this OIB-P-type mid-ocean ridge (MOR) oceanic lithosphere at an intraoceanic subduction zone produced the $\sim 130-120$ Ma forearc to backarc, SSZ oceanic crust within the same Neotethys. The evolutionary history of the YZSZ ophiolites thus reflects a poly-phase melt history and different mantle melt sources. The final tectonic juxtaposition of the older OIBand P-type oceanic crustal rocks with SSZ-type oceanic lithosphere fragments took place as the northern passive continental margin of Proto-India collided with and underplated the intraoceanic subduction-accretion system in the late Cretaceous. The YZSZ displays a complete Wilson cycle record of the rift-drift, seafloor spreading and subduction zone tectonic evolution of the Mesozoic Neotethys.

\section{Introduction}

The geochemistry and geochronology of the YZSZ ophiolites have been studied extensively during the last twenty years, producing a vast database on the geochemical affinities of different ophiolites and the timing of oceanic crust formation prior to the India-Asia collision (Aitchison et al., 2000; Wang et al., 2000; Yin and Harrison, 2000; Dilek and Newcomb, 2003; Dupuis et al., 2005; Sun et al., 2005; Zhang et al., 2005; Zhou et al., 2005; Guilmette et al., 2008, 2009; Bédard et al., 2009; Dai et al., 2011a, b, 2012; Hébert et al., 2012; Liu et al., 2013; Chan et al., 2015; Xu et al., 2015a). Yet, the interpretations of the tectonic settings of ophiolite genesis, the igneous - metamorphic ages and emplacement mechanisms of ophiolites, and the subduction zone numbers and polarities involved in the evolution of Neotethys are highly diverse and still poorly constrained. The lack of systematic field-based structural work along the YZSZ and of the documentation of the internal structure and stratigraphy of the ophiolite massifs and mélange units is partly responsible for this problem.

In this paper we overview and document the geological occurrence and the geochemical characteristics of a special group of mafic rocks, which are spatially and temporally associated with the ophiolite units 
along the 2500-km-long YZSZ. Largely overlooked in the literature, the early Jurassic-early Cretaceous OIB-type and alkaline mafic rocks are tectonically interleaved with the ophiolite massifs, as well as occurring extensively in the mélange formations within the YZSZ and in the Jurassic-Cretaceous flysch deposits structurally beneath the YSZS. They are hence part of the rift-drift, seafloor spreading and subduction zone tectonic evolution of the Neotethyan oceanic lithosphere, evolved between India and Eurasia during the Mesozoic. In the first part of the paper we summarize the spatial distribution and the internal structure of the discrete ophiolite complexes and the associated OIB-type mafic rocks from west to east along the YZSZ. Using some of the most reliable discriminant diagrams, we discuss, based on the extant data, the geochemistry and geochemical characteristics of these OIB-type mafic rocks. We then present an internally coherent tectonic model, synthesizing the structure, petrology, geochemistry and geochronology of the YZSZ ophiolites and the OIB-type rocks associated with them. This paper is intended to stimulate further research and discussions on the YZSZ ophiolites and on the significance of the existence of mafic OIB-type and alkaline oceanic rocks in suture zones in general.

\section{Regional Geology of the Yarlung-Zangbo Suture Zone}

The crust of the Tibetan Plateau is made of a series of oceanic and continental terranes bounded by the A'nemaqin-Kunlun, Jinshajiang (JSZ), Bangong-Nujiang (BNSZ), Shuanghu-Dingqing, and Yarlung-Zangbo (YZSZ) suture zones (Fig. 1; Yin and Harrison, 2000; Zhang and Tang, 2009; Xu et al., 2015b). The Yarlung-Zangbo Suture Zone (YZSZ) in the southernmost part of the Tibetan Plateau is the youngest among these suture zones, and has been widely accepted to represent the India - Asia continental collision front with the remnants of the Neotethyan oceanic lithosphere exposed discontinuously along it (e.g., Allègre et al., 1984; Aitchison et al., 2000; Dupuis et al., 2005; Bédard et al., 2009; Zhang et al., 2010; Hébert et al., 2012). These Neotethyan ophiolites occur along two sub-parallel belts within the suture zone: the northern belt includes ophiolite complexes with upper mantle peridotites, gabbros, dikessills, extrusive sequences and pelagic-hemipelagic sedimentary rocks, whereas the southern belt consists mainly of peridotite massifs overlain by volcanic-sedimentary rocks. A discontinuous belt of a mélange unit, containing ophiolitic material, deep marine sedimentary rocks, and high-grade metamorphic rocks structurally underlies the ophiolites within the YSZS (Guilmette et al., 2008; Liu et al., 2015; Xu et al., 2015a).

A Mesozoic flysch unit, containing blocks of Upper Permian limestone, lower Triassic pelagic limestone, late Cretaceous calcschist, turbiditic rocks, serpentinite, gabbros, massive diabase, and pillow massive lavas structurally underlies the YZSZ in the south (Xu et al., 2015a, and the references therein). High-grade metamorphic rocks with highly deformed granitoid intrusions make up the Tethyan Himalaya Sequence structurally beneath the Mesozoic flysch unit (Fig. 1). This Tethyan Himalaya Sequence consists mainly of Proterozoic to Eocene siliciclastic and carbonate sedimentary rocks, interbedded with Paleozoic and Mesozoic volcanic rocks (Yin, 2006), collectively forming the passive margin units of Greater India.

The northern boundary of the YZSZ is a complex, tectonic zone with ophiolitic and mélange units structurally overlying the Xigaze forearc basin sequence (XG in Figure 1) and/or the Gangdese magmatic terrane (GMT in Figure 1) along N-vergent backthrusts

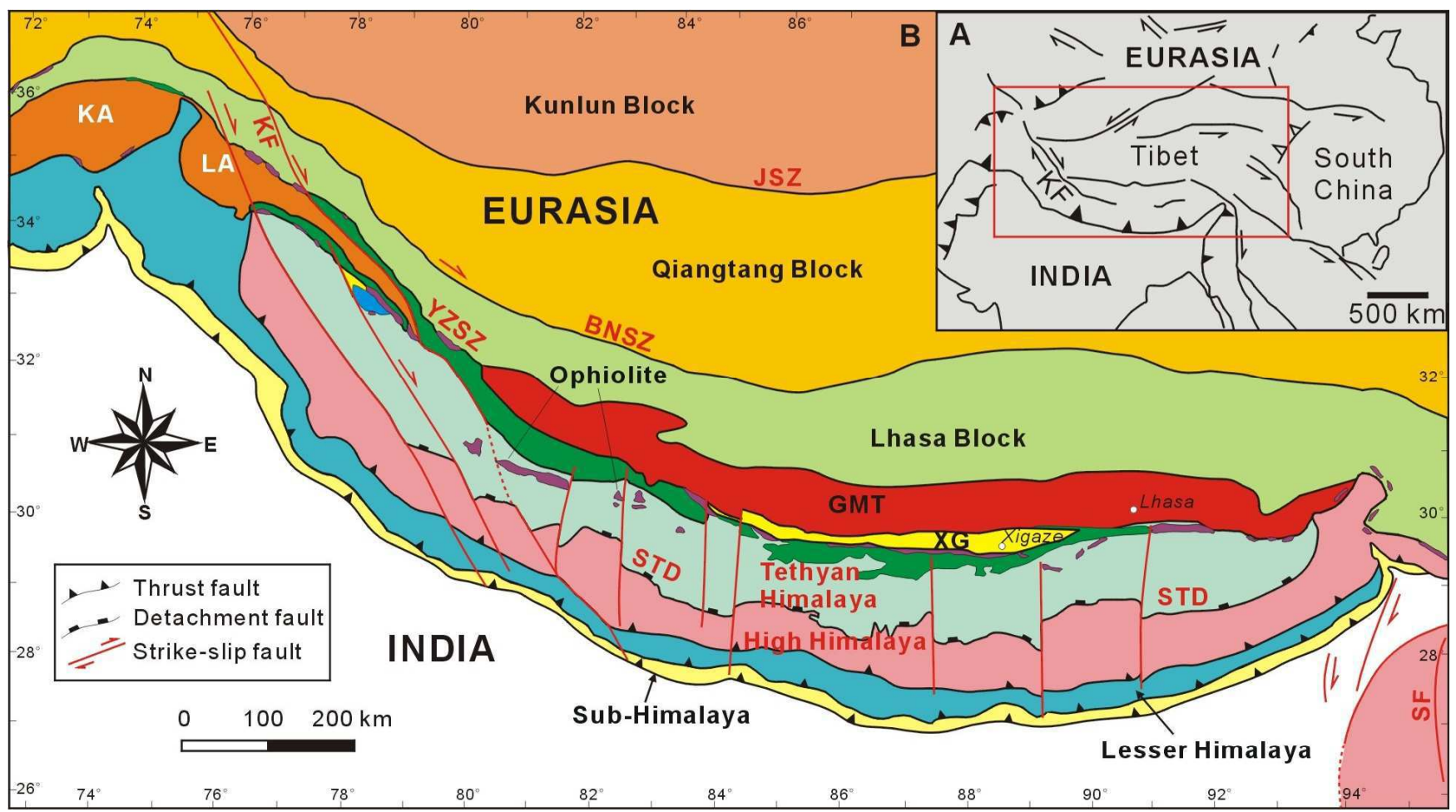

Figure 1. A-Index map of south-central Asia, depicting the major plates and major fault systems in the region. The red box outlines the map area in B. B-Simplified tectonic map of Southern Tibet, showing the major tectonic units, suture zones and fault systems. Key for abbreviations: BNSZ - Bangong Nujiang suture; JSZ - Jinshajing zone; KA - Kohistan arc; LA - Ladakh arc; STD - South Tibet Detachment; XG Xigaze forearc basin; YZSZ - Yarlung-Zangbo suture zone. 
(Xu et al., 2015a, and references therein). The Xigaze forearc basin sequence includes Cretaceous clastic units interbedded with marly carbonate layers (Einsele et al., 1994; Wang et al., 1999, 2012). The Gangdese magmatic terrane consists of late Jurassic to Paleogene calc-alkaline granitoids and andesitic-dacitic-rhyolitic volcanicvolcaniclastic sequences that collectively make up an Andean-type magmatic arc formed above a N-dipping subduction zone beneath the southern margin of Asia (Chung et al., 2005; Chu et al., 2006; Wen et al., 2008a, b; Ji et al., 2009).

\section{YZSZ ophiolites and associated OIB-type rocks}

The Yarlung-Zangbo ophiolites crop out along the YarlungZangbo River, and the main massifs include from west to east the Yungbwa, Xiugugabu, Dangqiong, Zhongba, Saga, Sangsang, Jiding, Xigaze, Zedong-Luobusa and the Eastern Himalayan Syntaxis ophiolites (Fig. 2). Recent geochronological and biostratigraphic studies in these ophiolites have revealed crystallization, deposition and metamorphic ages ranging from the middle Jurassic to the early Cretaceous; however, most of the igneous ages of the ophiolites are clustered at 130-120 Ma (Table 1; McDermid et al., 2002; Zhou, 2002; Malpas et al., 2003; Miller et al., 2003; Ziabrev et al., 2003; Wang et al., 2006; Wei et al., 2006a, b; Zhong et al., 2006; Chan et al., 2007; Guilmette et al., 2008, 2009; Li et al., 2008, 2009; Xia et al., 2008b; Dai et al., 2012). Petrological and geochemical studies of various crustal units (lavas, dikes, sills and gabbros) of the YZSZ ophiolites have indicated multi-stage melting episodes in different tectonic settings during their magmatic accretion and evolution, encompassing mid-ocean ridge, and backarc to forearc suprasubduction zone environments (Table 1; McDermid et al., 2002; Hébert et al., 2003; Xia et al., 2003; Dubois-Côté et al., 2005; Zhou et al., 2005; Bédard et al., 2009; Guilmette et al., 2008, 2009; Geng et al., 2010; Dai et al., 2011a, b; Bezard et al., 2011; Liu et al., 2010, 2012; Hébert et al., 2012; Dai et al., 2011b, 2013; Dilek and Furnes, 2014; Liu et al., 2015; Xu et al., 2015a). The Jurassic-Cretaceous mélange unit structurally beneath the YZSZ ophiolites includes coherent blocks of alkaline lavas, gabbros and dikes, and these lithologies are also tectonically interleaved with the ophiolitic units and their volcanic-sedimentary sequences.

In this section we describe the internal structure and stratigraphy of some of the discrete YZSZ ophiolite massifs and the alkaline rock suites spatially associated with them from west to east along the YZSZ. The geographic distribution of the investigated ophiolite massifs is shown in Figure 2. Table 1 summarizes the details of the extant age data from the YZSZ ophiolites and the data sources. The geochemistry of these alkaline rock suites is discussed in the following section.

\section{Dongbo ophiolite}

The Neotethyan ophiolites in the westernmost part of the YZSZ occur in two sub-parallel belts (Fig. 2), separated by the ZhongbaZhada crustal block (Liu et al., 2015; Xu et al., 2015a). The northern sub-belt largely displays a mélange character, whereas the southern sub-belt consists of discontinuous exposures of ophiolites with maficultramafic and volcanic-sedimentary sequences. The Dongbo and

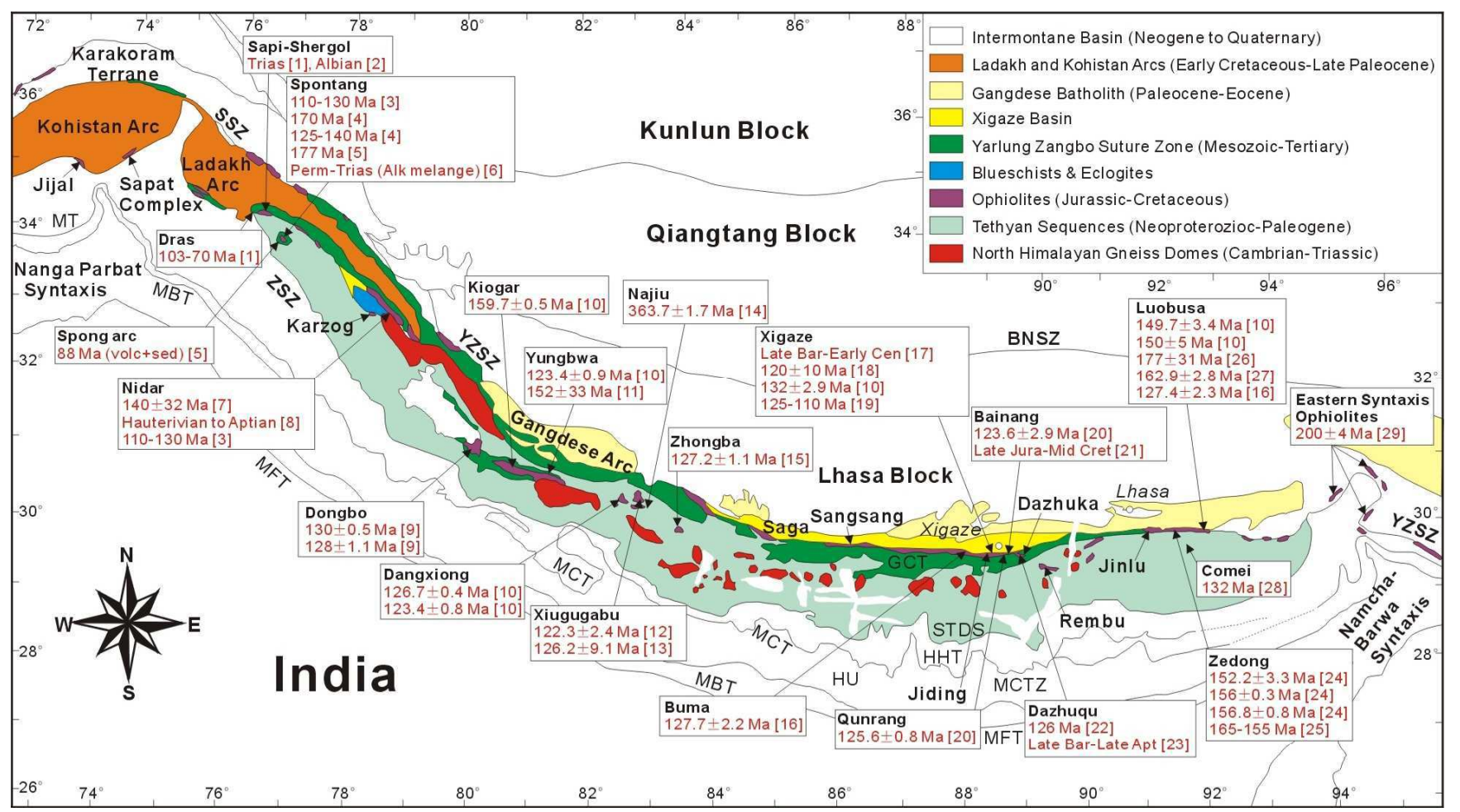

Figure 2. Simplified tectonic map of the Himalaya-Tibet orogenic belt and the Yarlung-Zangbo suture zone, showing the distribution and the ages of the major ophiolite massifs from west to east along the Yarlung-Zangbo suture zone. Data sources are listed in Table 1. Abbreviations: SSZ - Shyok suture zone; ZSZ - Zanskar suture zone; BNSZ - Bangong Nujiang suture; YZSZ - Yarlung-Zangbo Suture Zone. The Himalayan fold-thrust belt is subdivided into structural blocks according to the major discontinuities: GCT - Great Counter thrust; STD - South Tibet detachment; HHT - High Himalaya thrust; MCTZ - Main Central thrust zone; MBT - Main Boundary thrust; MFT - Main Frontal thrust. Data for the map from Yin and Harrison (2000), Goscombe et al. (2006), and Hébert et al. (2012). 
Table 1. Summary of the existing geochronological - biostratigraphic data from the Yarlung-Zangbo suture zone ophiolites and OIBtype rocks and key for the references used in Figure 1.

\begin{tabular}{|c|c|c|}
\hline Locality & Dating method & References \\
\hline Sapi-Shergol mélange & ${ }^{1 \text { and } 2} \mathrm{Rb}-\mathrm{Sr}$ on mica and radiolarian cherts & $\begin{array}{l}{ }^{1} \text { Honneger et al. (1982) } \\
{ }^{2} \text { Sihna and Mishra (1997) }\end{array}$ \\
\hline Dras & 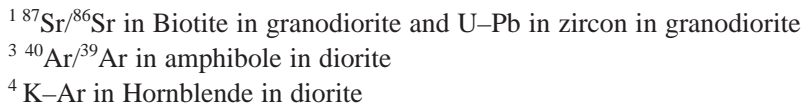 & $\begin{array}{l}{ }^{1} \text { Honneger et al. }(1982) \\
{ }^{3} \text { Mahéo et al. (2004) } \\
{ }^{4} \text { Reuber et al. (1989) }\end{array}$ \\
\hline Spongtang & $\begin{array}{l}{ }^{5} \mathrm{U}-\mathrm{Pb} \text { in zircon in plagiogranite } \\
\mathrm{K}-\mathrm{Ar} \text { in hydrothermal hornblende in calc-alkaline volcanics }\end{array}$ & $\begin{array}{l}{ }^{5} \text { Pedersen et al. }(2001) \\
{ }^{6} \text { Reuber et al. (1987) }\end{array}$ \\
\hline Spong arc & ${ }^{5} \mathrm{U}-\mathrm{Pb}$ in zircon in andesite & ${ }^{5}$ Pedersen et al. (2001) \\
\hline Nidar & $\begin{array}{l}{ }^{3}{ }^{39} \mathrm{Ar} /{ }^{40} \mathrm{Ar} \text { in amphibole in basaltic andesite } \\
{ }^{7147} \mathrm{Sm} /{ }^{144} \mathrm{Nd} \text { in clinopyroxene, plagioclase and whole rock in gabbro } \\
{ }^{8} \text { Radiolarian fossils }\end{array}$ & $\begin{array}{l}{ }^{3} \text { Mahéo et al. (2004) } \\
{ }^{7} \text { Ahmad et al. (2008) } \\
{ }^{8} \text { Kojima et al. (2001) }\end{array}$ \\
\hline Dongbo & ${ }^{9} \mathrm{U}-\mathrm{Pb}$ in zircon in pyroxenite and gabbro & ${ }^{9}$ Xiong et al. (2011) \\
\hline Kiogar & ${ }^{10} \mathrm{U}-\mathrm{Pb}$ in zircon in cumulate gabbro & ${ }^{10}$ Chan et al. (2007) \\
\hline Yungbwa & $\begin{array}{l}{ }^{10} \mathrm{U}-\mathrm{Pb} \text { Zircon in gabbro } \\
{ }^{11}{ }^{40} \mathrm{Ar} /{ }^{39} \mathrm{Ar} \text { in Magnesio Hornblende in basalt }\end{array}$ & $\begin{array}{l}{ }^{10} \text { Chan et al. }(2007) \\
{ }^{11} \text { Miller et al. (2003) }\end{array}$ \\
\hline Dangxiong & ${ }^{10} \mathrm{U}-\mathrm{Pb}$ Zircon in gabbro & ${ }^{10}$ Chan et al. (2007) \\
\hline Xiugugabu & $\begin{array}{l}{ }^{12} \mathrm{U}-\mathrm{Pb} \text { in zircon in micro-gabbro } \\
{ }^{13} \mathrm{Sm}-\mathrm{Nd} \text { in micro-gabbro }\end{array}$ & $\begin{array}{l}{ }^{12} \text { Wei et al. }(2006 b) \\
{ }^{13} \mathrm{Xu} \text { et al. }(2008)\end{array}$ \\
\hline Najiu & ${ }^{14} \mathrm{U}-\mathrm{Pb}$ in zircon in gabbro & ${ }^{14}$ Dai et al. (2011b) \\
\hline Zhongba & ${ }^{15} \mathrm{U}-\mathrm{Pb}$ in zircon in diabase & ${ }^{15}$ Dai et al. (2012) \\
\hline $\begin{array}{l}\text { Buma } \\
\text { Xigaze }\end{array}$ & ${ }^{16}{ }^{40} \mathrm{Ar} /{ }^{39} \mathrm{Ar}$ in hornblende in amphibolite & ${ }^{16}$ Guilmette et al. (2009) \\
\hline Mamidhuorong, & ${ }^{18} \mathrm{U}-\mathrm{Pb}$ in whole rock basalt, diabase and gabbro & ${ }^{17}$ Burg and Chen (1984) \\
\hline Qumei, Baigang, Lhazexian, & ${ }^{10} \mathrm{U}-\mathrm{Pb}$ in zircon in pegmatitic gabbro & ${ }^{18}$ Göpel et al. (1984) \\
\hline $\begin{array}{l}\text { Beilie, Xiadamei, Zisong, } \\
\text { (Pazuo, Dayu) }\end{array}$ & ${ }^{19}$ Radiolaires & $\begin{array}{l}{ }^{10} \text { Chan et al. (2007) } \\
{ }^{19} \text { Zyabrev et al. (1999) }\end{array}$ \\
\hline Qunrang & ${ }^{20}{ }^{40} \mathrm{Ar} /{ }^{39} \mathrm{Ar}$ in hornblende in amphibolite & ${ }^{20}$ Guilmette et al. (2007) \\
\hline Bainang & $\begin{array}{l}{ }^{20}{ }^{40} \mathrm{Ar} /{ }^{39} \mathrm{Ar} \text { in hornblende in amphibolite } \\
{ }^{21} \text { Radiolarian fossils }\end{array}$ & $\begin{array}{l}{ }^{20} \text { Guilmette et al. (2007) } \\
{ }^{21} \text { Ziabrev et al. (2003) }\end{array}$ \\
\hline Dazhuqu & $\begin{array}{l}{ }^{22} \mathrm{U}-\mathrm{Pb} \text { in zircon in quartz-diorite } \\
{ }^{23} \text { Radiolarian fossils }\end{array}$ & $\begin{array}{l}{ }^{22} \text { Malpas et al. (2003) } \\
{ }^{23} \text { Ziabrev et al. (2003) }\end{array}$ \\
\hline Zedang & $\begin{array}{l}{ }^{24}{ }^{40} \mathrm{Ar} /{ }^{39} \mathrm{Ar} \text { in Hornblende in andesite and } \mathrm{U}-\mathrm{Pb} \text { in zircon and } \\
{ }^{40} \mathrm{Ar} /{ }^{39} \mathrm{Ar} \text { in hornblende in quartz-diorite }\end{array}$ & ${ }^{24}$ McDermid et al. (2002) \\
\hline & ${ }^{25}$ Radiolarian fossils & ${ }^{25}$ Hébert et al. (2012) \\
\hline Luobusa & $\begin{array}{l}{ }^{16}{ }^{40} \mathrm{Ar} /{ }^{39} \mathrm{Ar} \text { in hornblende in amphibolite } \\
{ }^{10} \mathrm{U}-\mathrm{Pb} \text { in zircon in diabase }\end{array}$ & $\begin{array}{l}{ }^{16} \text { Guilmette et al. (2009) } \\
{ }^{10} \text { Chan et al. (2007) } \\
{ }^{26} \text { Zhou et al. (2002) } \\
{ }^{27} \text { Zhong et al. (2006) }\end{array}$ \\
\hline Comei & ${ }^{28} \mathrm{U}-\mathrm{Pb}$ in zircon in basalt and gabbro & ${ }^{28}$ Zhu et al. (2009) \\
\hline Eastern Syntaxis & ${ }^{29}{ }^{40} \mathrm{Ar} /{ }^{39} \mathrm{Ar}$ in clinopyroxene in ultramafic rock & ${ }^{29}$ Geng et al. (2006) \\
\hline
\end{tabular}

Purang ophiolites are situated within the southern sub-belt and are tectonically underlain by a Cretaceous ophiolitic mélange (Liu et al., 2015).

The Dongba ophiolite consists of a volcanic-sedimentary sequence, gabbros, and peridotites with dolerite and pyroxenite dikes. Its volcanic-sedimentary sequence rests directly on the serpentinized peridotites and includes basaltic lavas, volcaniclastic rocks, tuffaceous layers, limestone, red radiolarian chert, and silty shale-sandstone intercalations. Peridotites are composed of harzburgite and dunite with minor lherzolite. Cr-spinels of the Dongbo lherzolite have Cr\# $[\mathrm{Cr} /(\mathrm{Cr}+\mathrm{Al})]$ of $0.2-0.3$, whereas $\mathrm{Cr} \#$ of the harzburgite range from 0.2 to 0.75 . U-Pb zircon dating of pyroxenite and gabbro dikes in the harzburgites by LA-ICP-MS has yielded crystallization ages of $130 \pm 0.5 \mathrm{Ma}$ and $128 \pm 1.1 \mathrm{Ma}$, respectively, for the Dongbo ophiolite (Fig. 2; Xiong et al., 2011).

\section{Xiugugabu massif}

The Xiugugabu ophiolite also occurs in the southern sub-belt in the western YZSZ (Fig. 2) and tectonically overlies the same early
Cretaceous mélange to the south as the Dongbo massif. It is composed of harzburgite and clinopyroxene (cpx)-harzburgite intruded by amphibole-bearing micro-gabbro and micro-gabbronorite sills (Bezard et al., 2011). These sill intrusions and their host harzburgites show ductile deformation structures and mylonitic foliation of hightemperature origin. A massive diabase unit stratigraphically overlain by siltstone and hyaloclastic volcanic rocks is faulted against the peridotites in the north. Diabasic rocks have tholeiitic basalt compositions with Mg\#s of 0.60-0.63 that are distinctly different from those of the sill intrusions (Mg\#s of 0.74-0.86), and show OIB (ocean island basalt) geochemical affinities with a slight crustal contamination fingerprint (Bezard et al., 2011). The Cr\#s of the spinel-bearing harzburgites and the cpx-harzburgites vary between 0.20 and 0.80 . Bezard et al. (2011) inferred that these upper mantle peridotites might have undergone less than $25 \%$ partial melting beneath a mid-ocean ridge spreading center, followed by a refertilization process in a suprasubduction zone setting. Sm-Nd whole-rock and $\mathrm{U}-\mathrm{Pb}$ zircon dating of micro-gabbro sill rocks in the peridotites has revealed the crystallization ages of 126.2 $\pm 9.1 \mathrm{Ma}$ and $122.3 \pm 2.4 \mathrm{Ma}$, respectively, for the Xiugugabu massif (Fig. 2; Wei et al., 2006b; Xu et al., 2008). 


\section{Zhongba massif}

The Zhongba massif occurs west of the $84^{\circ} \mathrm{E}$ Longitude along the YZSZ (Fig. 2). It makes up a large thrust-sheet within the early Cretaceous mélange, and is tectonically underlain by large blocks of massive diabase and pillow lava rocks. The mélange also includes blocks of chert, limestone and massive basalt.

The Zhongba massif is composed entirely of harzburgites with minor dunite. The Cr-spinels in the harzburgites have Cr\# of 0.360.56 and $\mathrm{Mg \# s}$ ranging from 0.57 to 0.72 (Dai et al., 2011b). These highly depleted harzburgites show variable relative enrichment in the most incompatible trace elements, characteristic of subductioninfluenced mantle wedge peridotites beneath forearc settings (Parkinson and Pearce, 1998). Diabasic rocks and pillow basalts tectonically below the Zhongba thrust sheet exhibit trace element patterns that are similar to those of the average OIB, Hawaiian alkaline basalts, and OIB-type rocks documented from the other Neotethyan ophiolites along the west-central YZSZ. Zircon U-Pb dating of a diabasic rock sample has yielded a crystallization age of $125.7 \pm 0.9$ Ma (Dai et al., 2012), which is consistent with the reported igneous ages of crustal rocks from the other YZSZ ophiolites (Table 1).

\section{Saga massif}

The Saga massif occurs just east of the $85^{\circ} \mathrm{E}$ Longitude and forms a $\sim 25$-km-long thrust sheet, tectonically overlying the early Cretaceous ophiolitic mélange to the south (Fig. 2). The mélange contains blocks of lherzolitic, dunitic peridotites and garnet- and cpxbearing amphibolites in a serpentinite matrix (Bédard et al., 2009; Guilmette et al., 2012). Structurally below this mélange in the south is a 2- to 2.5-km-thick unit of meta-gabbro, amphibolite and metabasaltic rocks that is in turn tectonically underlain by a $\sim 2-\mathrm{km}$-thick sequence of pillow to massive lavas, diabasic rocks, and Triassic green-red chert.

The upper mantle peridotites in the Saga massif consist of lherzolite and cpx-harzburgite with spinels that have typical Mg\#s of 0.70-0.79 and Cr\#s of 0.10-0.22 (Bédard et al., 2009). Their trace element patterns resemble those of abyssal peridotites, which experienced low degrees of partial melting (5-12\%). Pillow and massive lavas, diabasic rocks, meta-basalts and amphibolites beneath the peridotite massif show incompatible element abundances similar to those of N-MORB, but they also display slight negative Ti and Ta anomalies. The major and trace element geochemistry of the highgrade amphibolite blocks in the mélange suggest mafic protoliths with N-MORB to E-MORB affinities (Guilmette et al., 2012). ${ }^{40} \mathrm{Ar} /$ ${ }^{39} \mathrm{Ar}$ dating of hornblende separates from these amphibolites has revealed cooling ages of 132-127 Ma (Guilmette et al., 2012).

\section{Sangsang ophiolite}

The 100 -km-long Sangsang ophiolite occurs to the east of the Saga massif, between the $86^{\circ} \mathrm{E}$ and $87^{\circ} \mathrm{E}$ Longitudes (Fig. 2). Similar to Saga, it tectonically overlies the early Cretaceous ophiolitic mélange to the south, and is separated from the clastic rock sequences of the Cretaceous Xigaze Group to the north by a major fault. The ophiolitic mélange includes blocks of harzburgitic peridotites, alkaline volcanic rocks, sandstone-chert, and is tectonically juxtaposed against the Triassic flysch unit to the south.
The Sangsang massif consists mainly of tectonized peridotites overlain to the north by a thin sliver $(<1 \mathrm{~km})$ of gabbro, massive diabase and pillow lavas. The Sangsang peridotites are composed of harzburgite and cpx-harzburgite with spinels having Cr\#s of 0.30 0.60 , typical of abyssal or forearc mantle peridotites (Bédard et al., 2012). Their trace element characteristics suggest partial melting degrees of $17-30 \%$, higher than those estimated for the peridotites in the Saga massif. Massive diabase and pillow lavas above the peridotites are enriched in incompatible elements, typical of OIB lavas. Alkaline volcanic rocks occurring as blocks in the ophiolitic mélange beneath the Sangsang massif also display OIB affinities (Hébert et al., 2012). The U-Pb SHRIMP dating of zircons from diabasic rocks has revealed a crystallization age of 125.23 Ma (Xia et al., 2008b).

\section{Xigaze ophiolite}

The Xigaze ophiolite occurs between the $88^{\circ} \mathrm{E}$ and $89^{\circ} 30^{\prime} \mathrm{E}$ Longitudes in the central part of the YZSZ (Fig. 2) and includes the Dazhuqu, Deji, Qunrang, Luqu and Jiding massifs. It is the biggest and most complete ophiolite complex along the entire YZSZ. It tectonically overlies the early Cretaceous ophiolitic mélange to the south along an originally S-vergent thrust fault; however, the late Triassic-early Jurassic flysch sequence south of the YZSZ, the ophiolitic mélange and the Xigaze ophiolite are all imbricated along $\mathrm{N}$-vergent backthrusts, and rest structurally above the late Cretaceous and younger clastic rock sequences of the Xigaze Group in the north (Xu et al., 2015a).

In general, the Xigaze ophiolite consists of upper mantle peridotites, ultramafic cumulates, doleritic and gabbroic dike-sill intrusions in the peridotites, thin $(<300 \mathrm{~m})$ gabbro-gabbronorite rocks in some massifs, and an extrusive sequence composed of pillow and massive lavas and tuffaceous volcaniclastic rocks, which are intercalated with radiolarian chert deposits near the top of the extrusive sequence. Siliceous mudstone, chert, radiolarite and fine-grained clastic rocks make up a sedimentary cover of the ophiolite.

The upper mantle units comprise harzburgite, cpx-harzburgite and lherzolite with minor occurrences of dunite and chromitites. The $\mathrm{Mg} \#$ of these peridotites is in the range of $90.0-92.8$, and the Cr\# of spinels is in the range of 79 to 81 (Bao et al., 2013; Dai et al., 2013). The whole-rock compositions indicate their residual, highly refractory nature, which reflect $15 \%$ to $24 \%$ partial melting. The U-shaped REE patterns of some of the Xigaze harzburgites suggest their reactioninteraction with boninitic melts in a mantle wedge, as also reported from other Neotethyan ophiolites (Dilek and Thy, 1998, 2009; DuboisCoté et al., 2005; Dilek et al., 2008; Dilek and Furnes, 2009; Bao et al., 2013; Dai et al., 2013).

The majority of doleritic and gabbro dike-sill intrusions and lavas show LREE depletion similar to N-MORB patterns, and enrichment in LILE and $\mathrm{Pb}$ and negative $\mathrm{Nb}-\mathrm{Ta}$ anomalies, suggesting minor subduction influence in their melt evolution. Some dikes and lavas, on the other hand, display distinctive U-shaped boninitic patterns on N-MORB normalized trace element diagrams. Blocks of mafic lavas and gabbros in the Triassic flysch sequence beneath the ophiolitic mélange of the Xigaze ophiolite have strong OIB geochemical signatures, indicating their origin from within-plate alkaline magmas (Dupuis et al., 2005; Hébert et al., 2012).

$\mathrm{U}-\mathrm{Pb}$ zircon dating of doleritic dikes in the mantle peridotites of the Dazhuqu and Deji sub-massifs has revealed crystallization ages of $126.1 \pm 1.3 \mathrm{Ma}$ and $124.9 \pm 1.1 \mathrm{Ma}$, respectively; a dolerite sill 
intrusion in the Deji sub-massif has given a weighted zircon U-Pb mean age of $126.5 \pm 4.7 \mathrm{Ma}$ (Table 1). The youngest crystallization age of $123.3 \pm 1.5 \mathrm{Ma}$ was obtained from a quartz diorite dike in the Deji peridotite (Dai et al., 2013). The Xigaze ophiolite, thus, displays a narrow age range of $127 \mathrm{Ma}$ to $124 \mathrm{Ma}$ for its late-stage mafic and felsic intrusive rocks. There are no age data available from the alkaline rocks, but their close spatial association with ophiolitic peridotites within the flysch near Renbu suggests that they are not significantly older than the early Cretaceous ages of the YZSZ ophiolites.

\section{Luobusa-Lang County ophiolites}

The Luobusa-Lang County ophiolite belt (Fig. 2) is situated in the eastern end of the YZSZ between $92^{\circ}$ and $93^{\circ}$ of longitudes, and includes the Kangjinla, Luobusa and Baozhigou massifs to the east, the Sangri, Chenbaxiang and Gongbar massifs in the center, and the Zedang massif to the west. This entire ophiolite belt is bounded by two regional, south-dipping, ductile to ductile-brittle thrust faults, the South Luobusa-Zedang thrust (SLZT) and the North LuobusaZedang thrust (NLZT) (Liang et al., 2011; Xu et al., 2015b). A highly deformed late Triassic flysch sequence is thrust over the ophiolite belt along the E-W-striking and steeply south-dipping SLZT. The NLZT represents a steeply south-dipping, 200- to 300-m-thick, ductile shear zone, which puts the ophiolitic peridotites on top of the Paleogene Liuqu Conglomerate in the north (Xu et al., 2015a).

In the Kangjinla-Luobusa area, the SLZT consists of mylonitic flysch rocks in its upper and mylonitic peridotites in its lower parts. The late Triassic flysch unit is composed of shale, siltstone-sandstone, and blocks of marble and quartz listwanite. The Luobusa ophiolite in this area constitutes a $\sim 40$ - to 50-km-long and up to $\sim 4$-km-wide mafic-ultramafic slab that is thrust northward onto the Gangdese batholith and the Cenozoic terrestrial strata (Yang et al., 2015b). However, an ophiolitic mélange composed of blocks of pillow lavas, volcanic breccia, chert, marble, shale, isotropic gabbro and pyroxenite in a highly sheared serpentinite matrix underlies the ophiolite along its northern margin. Serpentinized peridotites in the mélange are transitional upward into a 300-m-thick dunite unit, which is overlain by cpx-harzburgites with chromitite bands and pods (Yang et al., 2015b). Structurally upward in the Luobusa ophiolite and overlying the cpx-harzburgites are depleted harzburgites with lenses and pods of chromitite enveloped by dunite (Huang et al., 1981; Zhou et al., 1996, 2002, 2005, 2014; Malpas et al., 2003; Hébert et al., 2003; Robinson et al., 2004; Shi et al., 2007; Yamamoto et al., 2007, 2009; Yang et al., 2007, 2014; Xu et al., 2011, 2014; Xiong et al., 2014).

A detailed account of the petrology and geochemistry of the Luobusa peridotites and crustal units is presented by Yang et al. (2015this issue). The highly depleted upper harzburgites and the lessdepleted cpx-bearing lower harzburgites represent the residues of highdegrees and low-degrees of melting, respectively (Bao et al., 2014). All these peridotites display variously depleted, U-shaped REE patterns, characteristic of those mantle wedge peridotites beneath forearc settings (Parkinson and Pearce, 1998).

The Sangri, Chenbaxiang and Gongbar massifs in the center of the Luobusa-Lang County ophiolite belt are highly dismembered by numerous thrust faults, and occur as blocks in meters to tens of meters in size within an Upper Jurassic to Lower Cretaceous volcanicsedimentary sequence. The late Triassic flysch unit to the south tectonically rests on this volcanic-sedimentary sequence along the
SLZT. Farther west, the Zedang massif occurs as a S-dipping thrust sheet sandwiched between the late Triassic flysch to the south and the late Cretaceous andesitic volcanic rocks of the Gangdese magmatic terrane to the north (Xu et al., 2015a). The ophiolite contains peridotites, podiform chromitites, gabbro, doleritic dikes and volcanic rocks, which are in places tectonically intercalated with middle-late Cretaceous sandstone, phyllite and radiolarite. The Zedang peridotites are composed of cpx-harzburgite, harzburgite with minor lherzolite and dunite (Bao et al., 2014). Volcanic rocks with MORB, island arc tholeiite (IAT) and boninitic geochemical affinities and REE patterns coexist within the Zedang extrusive rock suites (Bao et al., 2014).

The Lang County ophiolite is $70-\mathrm{km}$-long and constitutes the eastern extension of the Luobusa ophiolite. It includes upper mantle peridotites composed of harzburgite and dunite, and minor occurrences of meta-gabbro, meta-basalts, pillow basalts, dolerite sills and dikes. Basaltic lavas display E-MORB and OIB geochemical affinities.

The Luobusa cpx-harzburgites are crosscut by numerous gabbroic dikes. $\mathrm{U} / \mathrm{Pb}$ zircon dating of one of these dike rocks has revealed a crystallization age of $148 \pm 4.5 \mathrm{Ma}$ (Chan et al., 2007), which is considered as the minimum age of the ophiolite. $\mathrm{U}-\mathrm{Pb}$ zircon dating of basaltic rocks from the Lang County ophiolite has yielded crystallization ages of $145.7 \pm 2.5 \mathrm{Ma}$ and $147.8 \pm 3.3 \mathrm{Ma}$ (Zhang et al., 2011). However, gabbroic rocks from the same ophiolite have provided U-Pb zircon ages of 191.4 $\pm 3.7 \mathrm{Ma}$ (Zhang et al., 2011). These limited age data from the Luobusa-Lang County ophiolites indicate much older magmatic ages from the eastern part of the YZSZ, suggesting that the Neotethyan oceanic lithosphere formation in this part of southern Tibet might have extended further back into the early Jurassic in the east.

\section{Eastern Syntaxis ophiolites (ESO)}

These ophiolites are situated at the extreme eastern end of the YZSZ where the Tethyan suture zone makes a sharp hairpin turn to the south between $95^{\circ}$ and $96^{\circ}$ of longitude and encounters the N-Soriented, dextral Sagaing Fault (Fig. 1), which separates the Burma microplate in the west from the Sundaland to the east. Ophiolitic lithologies, composed of boninitic dolerite, arc tholeiite, back-arc basalt, amphibolite, and alkaline mafic rocks, occur as dismembered and metamorphosed blocks within a $\sim \mathrm{N}-\mathrm{S}$-trending mélange zone (Geng et al., 2010; Hébert et al., 2012; Ghose et al., 2014; Fareeduddin and Dilek, 2015). Geochronological data from the Eastern Syntaxis ophiolites in China are nearly non-existent. ${ }^{40} \mathrm{Ar} /{ }^{39} \mathrm{Ar}$ dating of clinopyroxene separates from an ultramafic rock has revealed a cooling age of $200 \pm 4 \mathrm{Ma}$ (Geng et al., 2006). This age is consistent with the U/Pb zircon age of $191.4 \pm 3.7 \mathrm{Ma}$, obtained from the Lang County ophiolite directly to the north. ${ }^{40} \mathrm{Ar} /{ }^{39} \mathrm{Ar}$ dating of feldspar grains from the earliest subduction-related granites found along the suture zone has provided an age range of 94 to $79 \mathrm{Ma}$ (Geng et al., 2006).

\section{Geochemistry of the OIB-type and alkaline rocks}

We have examined the extant geochemical data available in the literature from all alkaline rocks associated with the YZSZ ophiolites as described above, and have screened the major element analyses in order to avoid those samples with high LOI (loss on ignition) values. 
We have selected only those samples with $<5 \mathrm{wt} . \%$ LOI for the least altered samples analyzed, and have then compiled the high-quality data from more than 60 rock samples, including lavas, massive diabase, and gabbros with OIB affinities. A list of the most representative rock samples used in this study and their compositional names together with the ophiolite location and the data sources (references) is given in Table 2. We present the compiled trace element and REE data in Table 3.

The chondrite normalized REE patterns and the primitive mantle normalized trace element spider diagrams are shown in Figures 3 and 4 , respectively. The average trends of modern OIB, E-MORB, NMORB and Hawaiian alkaline basalts are also shown on these plots for comparison (after Sun and McDonough, 1989; Garcia et al., 1995; Hofmann and Jochum, 1996; Xu et al., 2007). All the OIB-like rocks associated with the YZSZ ophiolites display uniform chondrite normalized REE patterns with LREE enrichment and HREE depletion, and with no obvious Eu anomalies. Most of the evaluated samples resemble modern OIB (Sun and McDonough, 1989) and the Hawaiian alkaline basalts, although few show patterns similar to those of EMORB and N-MORBs (Fig. 3). In the primitive mantle normalized spidergrams (Fig. 4), the examined rocks display trends that are similar to those reported for the Hawaiian alkaline basalts and for the average OIB. There are no obvious negative $\mathrm{Nb}$, $\mathrm{Ta}$, and $\mathrm{Ti}$ anomalies.

Rocks produced from subduction-influenced magmas can be easily distinguished from OIB-type alkaline rocks on the V-Ti/1000 discrimination diagram of Shervais (1982). The individual V-Ti diagrams from all examined ophiolites along the YZSZ show that the OIB rock suites plot largely in the alkaline field (Fig. 5), although some rock samples straddle the MORB - Alkaline boundary as well as plotting in the MORB field. On the $\mathrm{Th} / \mathrm{Yb}$ versus $\mathrm{Nb} / \mathrm{Yb}$ discrimination diagram (Fig. 6) of Pearce (2008), the majority of the examined rock suites plot closer to the OIB domain within the mantle array, and overlap significantly with the Hawaiian alkaline basalt field shown in the upper right-corner (Key diagram). On the Nb-Zr-Y ternary discrimination diagram, most of the OIB-type rocks from the YZSZ fall in the within-plate alkaline and tholeiitic basalt fields, while few samples plot in the E-MORB field (Fig. 7; Meschede, 1986).

We also applied the binary diagrams of Saccani (2015), which utilize absolute measures of $\mathrm{Th}$ and $\mathrm{Nb}$ (normalized to the $\mathrm{N}-\mathrm{MORB}$ composition of Sun and McDonough, 1989), to find out whether the examined rock suites from the YZSZ ophiolites show any subduction zone influence or evidence for crustal contamination, and to better identify their MORB affinities (Fig. 8). Elemental ratios of the examined samples range from E-MORB to P-MORB (plume-type MORBs; Dilek and Furnes, 2011, 2014; Pearce, 2008; Saccani, 2015) and to those in alkaline basalts (Fig. 8A), showing a continuous compositional variation from the less enriched to the more enriched rocks. These rocks exhibit multi-element patterns significantly enriched in LILE compared to HFSE and HREE. The overall geochemistry of the majority of the samples resembles that of alkaline basalts generated in within-plate ocean island settings (Fig. 8A). In terms of their tectonic fingerprint, these alkaline samples from the YZSZ overlap with subduction unrelated rifted margin and oceancontinent transition zone (OCT) rocks (Fig. 8B; Saccani et al., 2015). Only a very few of them may show slight chemical influence of lower crustal contamination in their melt evolution. We hence infer that the YZSZ alkaline rocks were generated from partial melting of a MORBtype asthenospheric source enriched in LREE by an OIB type component (plume-type component).
Table 2. Summary of the extant geochemical data for the OIB-type mafic rocks from the YZSZ.

\begin{tabular}{|c|c|c|c|}
\hline Sample & Rock type & Location & Reference \\
\hline 11L36-1 & Basalt & Dongbo & Liu et al. (2013) \\
\hline 11L36-2 & Basalt & Dongbo & Liu et al. (2013) \\
\hline 11L36-4 & Basalt & Dongbo & Liu et al. (2013) \\
\hline 11L36-5 & Basalt & Dongbo & Liu et al. (2013) \\
\hline 11L37-1 & Basalt & Dongbo & Liu et al. (2013) \\
\hline $11 \mathrm{~L} 37-4$ & Basalt & Dongbo & Liu et al. (2013) \\
\hline 11L37-7 & Basalt & Dongbo & Liu et al. (2013) \\
\hline 11L37-8 & Basalt & Dongbo & Liu et al. (2013) \\
\hline 11L37-9 & Basalt & Dongbo & Liu et al. (2013) \\
\hline 09-ZH-56A & Diabase & Xiugugabu & Bezard et al. (2011) \\
\hline 09-ZH-57 & Diabase & Xiugugabu & Bezard et al. (2011) \\
\hline 09-ZH-58 & Diabase & Xiugugabu & Bezard et al. (2011) \\
\hline ZEOS-5-01 & Pillow basalt & Zhongba & Dai et al. (2012) \\
\hline ZEOS-5-03 & Pillow basalt & Zhongba & Dai et al. (2012) \\
\hline ZEOS-5-05 & Pillow basalt & Zhongba & Dai et al. (2012) \\
\hline ZEOS-5-08 & Pillow basalt & Zhongba & Dai et al. (2012) \\
\hline ZEOS-6-03 & Basalt & Zhongba & Dai et al. (2012) \\
\hline ZEOS-4-03 & Diabase & Zhongba & Dai et al. (2012) \\
\hline ZEOS-4-04 & Diabase & Zhongba & Dai et al. (2012) \\
\hline ZEOS-4-05 & Diabase & Zhongba & Dai et al. (2012) \\
\hline ZEOS-4-05R & Diabase & Zhongba & Dai et al. (2012) \\
\hline 06-SA-10C & Altered diabase & Saga & Bédard et al. (2009) \\
\hline 06-SA-16 & Brecciated basalt & Saga & Bédard et al. (2009) \\
\hline 07-SG-14 & Hematized basalt & Sangsang & Bédard et al. (2009) \\
\hline 07-SG-17A & Hematized basalt & Sangsang & Bédard et al. (2009) \\
\hline 07-SG-53 & Basalt & Sangsang & Bédard et al. (2009) \\
\hline 07-SG-61 & Andesite & Sangsang & Bédard et al. (2009) \\
\hline 07-SG-63A & Gabbro & Sangsang & Bédard et al. (2009) \\
\hline RB49 & Basalt & Rembu & Xia et al. (2008a) \\
\hline RB50 & Basalt & Rembu & Xia et al. (2008a) \\
\hline RB55 & Basalt & Rembu & Xia et al. (2008a) \\
\hline RB56 & Basalt & Rembu & Xia et al. (2008a) \\
\hline RB58 & Basalt & Rembu & Xia et al. (2008a) \\
\hline RB61 & Basalt & Rembu & Xia et al. (2008a) \\
\hline RB63 & Basalt & Rembu & Xia et al. (2008a) \\
\hline RB70 & Basalt & Rembu & Xia et al. (2008a) \\
\hline RB73 & Basalt & Rembu & Xia et al. (2008a) \\
\hline RB74 & Basalt & Rembu & Xia et al. (2008a) \\
\hline RB141 & Basalt & Rembu & Xia et al. (2008a) \\
\hline RB143 & Basalt & Rembu & Xia et al. (2008a) \\
\hline RB145 & Basalt & Rembu & Xia et al. (2008a) \\
\hline RB146 & Basalt & Rembu & Xia et al. (2008a) \\
\hline RB147 & Basalt & Rembu & Xia et al. (2008a) \\
\hline RB151 & Basalt & Rembu & Xia et al. (2008a) \\
\hline Lz-18 & Basalt & Cuolashan & Zhu et al. (2008) \\
\hline Lz-19 & Basalt & Cuolashan & Zhu et al. (2008) \\
\hline Lz-21 & Basalt & Cuolashan & Zhu et al. (2008) \\
\hline Lz-23 & Basalt & Cuolashan & Zhu et al. (2008) \\
\hline Sg-16 & Basalt & Sangdanlin & Zhu et al. (2008) \\
\hline W-8 & Basalt & Sangdanlin & Zhu et al. (2008) \\
\hline LX03-1 & Metabasalt & Lang county & Zhang et al. (2011) \\
\hline LX03-3 & Metabasalt & Lang county & Zhang et al. (2011) \\
\hline LX03-5 & Metabasalt & Lang county & Zhang et al. (2011) \\
\hline M-68 & Metabasalt & Eastern Syntaxis & Geng et al. (2010) \\
\hline M-114 & Metabasalt & Eastern Syntaxis & Geng et al. (2010) \\
\hline M-124 & Metabasalt & Eastern Syntaxis & Geng et al. (2010) \\
\hline M-125 & Metabasalt & Eastern Syntaxis & Geng et al. (2010) \\
\hline M-149 & Metabasalt & Eastern Syntaxis & Geng et al. (2010) \\
\hline M-153 & Metabasalt & Eastern Syntaxis & Geng et al. (2010) \\
\hline M-18 & Metabasalt & Eastern Syntaxis & Geng et al. (2010) \\
\hline L-21 & Metabasalt & Eastern Syntaxis & Geng et al. (2010) \\
\hline
\end{tabular}

\section{Tectonic evolution of the YZSZ ophiolites and the OIB-type rocks}

The YZSZ ophiolites display major variations in their magmatic and metamorphic ages, geochemical affinities and melt evolution patterns. However, almost all the ophiolite massifs and the early 


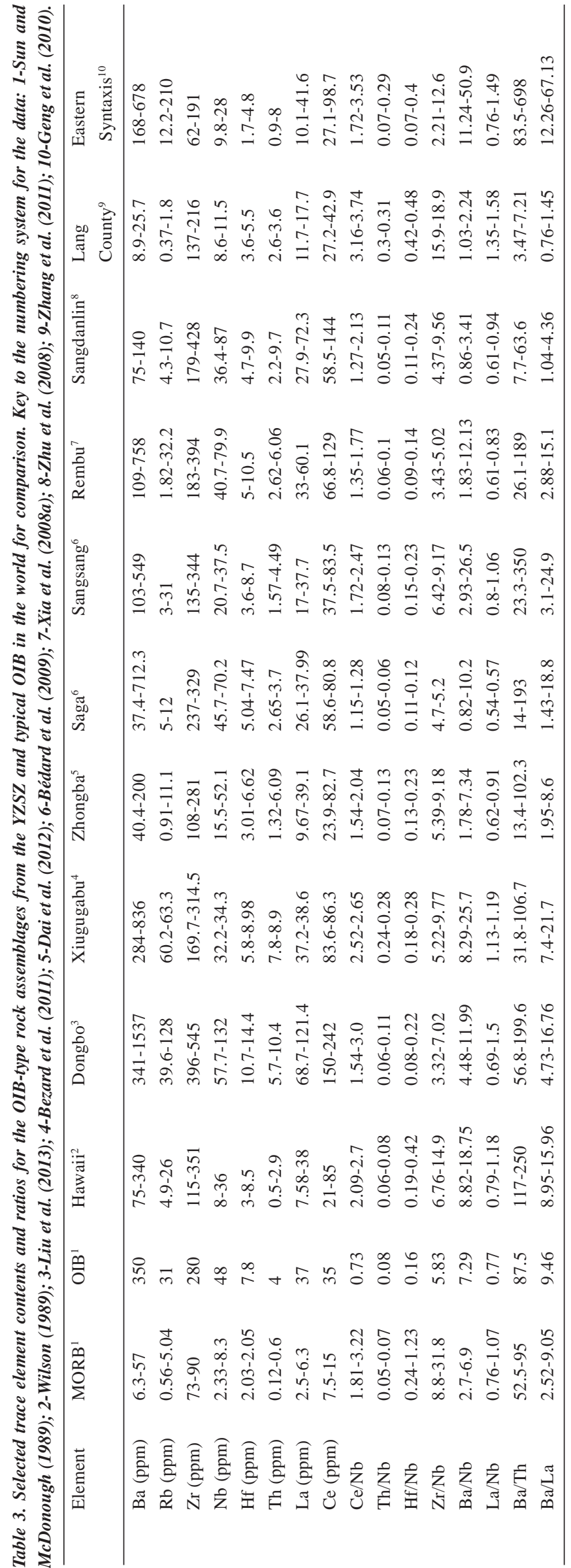

Cretaceous ophiolitic mélange units within the YZSZ are spatially and temporally associated with OIB-type rock associations, as documented in this study and in some previous studies (Dupuis et al., 2005; Zhang et al., 2005; Xia et al., 2008a; Zhu et al., 2008; Bezard et al., 2011). Geochemical features of these OIB-type extrusive and intrusive rocks are consistent with plume-influenced melt evolution of their magmas.

The YZSZ ophiolitic peridotites appear to have experienced twostage melt evolution and depletion events. The cpx-rich harzburgites in these peridotites are analogous to the upper mantle peridotites produced after low-degree melt extraction at a mid-ocean ridge setting. The second stage re-melting of these already depleted upper mantle peridotites (residues of the first stage MOR melting) created a higherdegree depleted mantle residue, after they became trapped in a mantle wedge above an intraoceanic subduction zone (Zhou et al., 1996, 2005; Huot et al., 2002; Dilek and Robinson, 2003, and references therein; Chen and Xia, 2008; Liu et al., 2010; Bezard et al., 2011; Dai et al., 2011b; Xu et al., 2015a). This second episode of melting of the already depleted mantle was responsible for the production of island arc tholeiite to boninitic melts enriched in light REE (due to the contribution from the subducting slab) (Dilek and Furnes, 2009; Dilek and Thy, 2009).

On the basis of these petrological - geochemical observations and interpretations, we have developed a tectonic model for the magmatic evolution of the YZSZ ophiolites and the associated OIBtype rock associations, following the model suggested by $\mathrm{Xu}$ et al. (2015a). In this refined model the oldest Neotethyan ophiolites (>180 - $140 \mathrm{Ma}$ ) that are currently exposed in the easternmost part of the YZSZ are inferred to have formed in a plume-proximal seafloor spreading system (Dilek and Furnes, 2011, 2014) within a Neotethyan seaway, which evolved between Proto-India and Eurasia (Fig. 9A). The oceanic lithosphere that formed during the rift-drift and seafloor spreading stages of the evolution of this Neotethyan seaway contains mafic rock associations produced by E-MORB, P-MORB and OIBtype melts, and fragments of these mafic rock assemblages widely occur within the Triassic through Jurassic-Cretaceous flysch units, the early Cretaceous ophiolitic mélange, and ophiolite complexes along the YZSZ. The role of plume magmatism and plumemetasomatized mantle chemistry in the petrogenetic evolution of riftdrift generated magmatic rocks exposed in suture zones is well documented in the literature (Dilek, 2003; Buiter and Torsvik, 2014).

In addition to the occurrence of P-type and OIB-type ophiolitic lithologies along the entire length of the YZSZ, there is another independent line of evidence for the potential involvement of a regional plume or mantle updraft event in the early history of Neotethys in southern Tibet. The peridotites and chromitite bodies in the Loubusa ophiolite contain in-situ diamonds and other ultrahighpressure (UHP) mineral inclusions (Yamamato et al., 2009; Yang et al., 2014, 2015a, 2015b, and references therein), suggesting that they might have initially originated under very high-temperature and highpressure conditions. The P-T estimates of the UHP mineral assemblages suggest that the chromitite formation might have initially begun within or near the mantle transition zone (Yang et al., 2015b, and references therein). The early, high-temperature deformation fabrics in the podiform chromitites and peridotites containing UHP inclusions appear to have developed during their ascent from the lower to the upper mantle by a regional-scale, plume-originated updraft (Fig. 9A; Yang et al., 2014). The upwelling OIB melt might have also contained methane fluids originated in the lower mantle, and these 


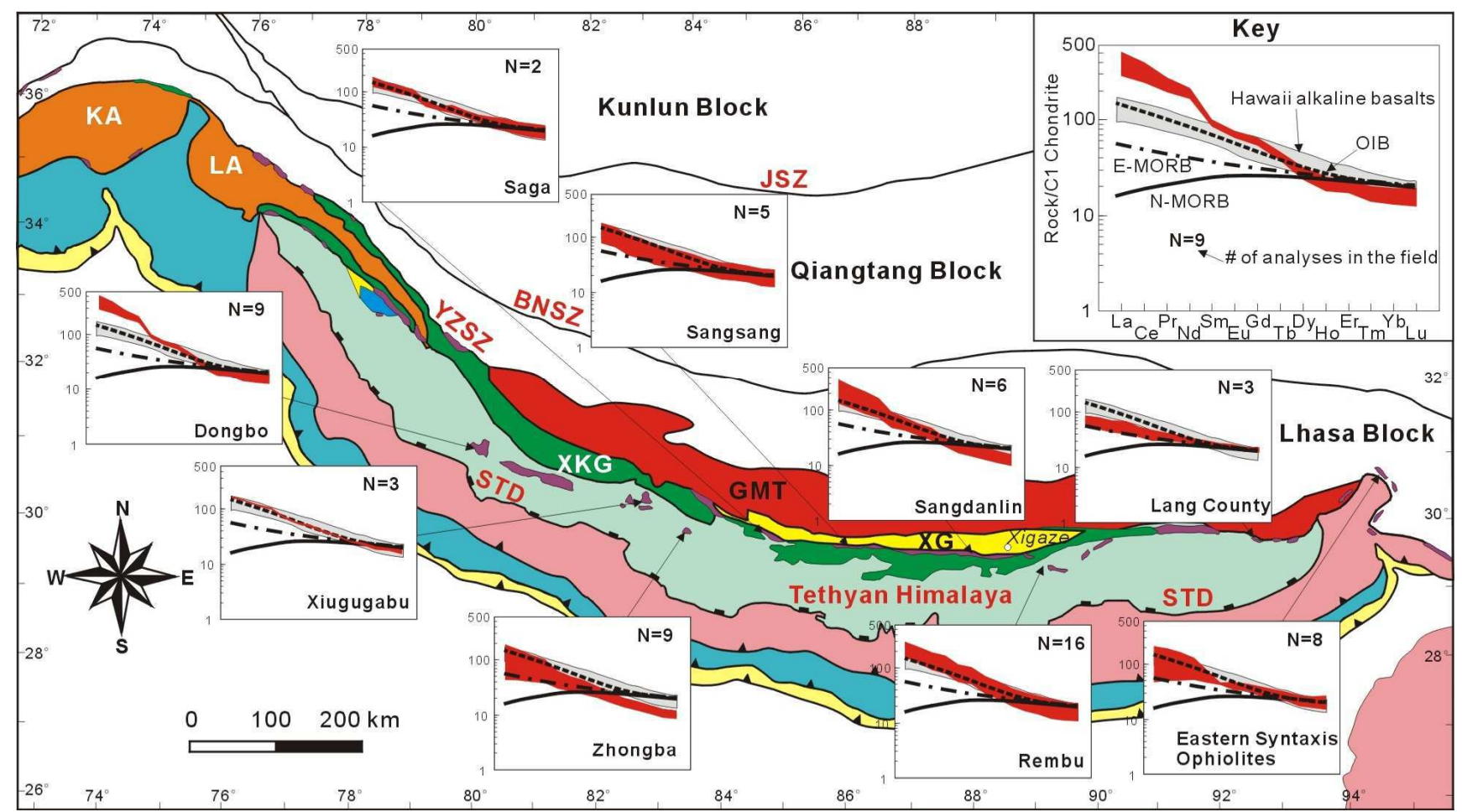

Figure 3. Chondrite-normalized REE diagrams for the OIB-type mafic rocks from the ophiolite massifs investigated in this study. Chondrite normalizing values, and the $N$-MORB, E-MORB, and OIB trends are from Sun and McDonough (1989). Data for the Hawaii alkaline basalt field are from Garcia et al. (1995), Hofmann and Jochum (1996), and Xu et al. (2007). Map symbols are the same as in Figure 1. Data sources for the chemical compositions of the OIB-type rocks from different ophiolite massifs are listed in Table 2.

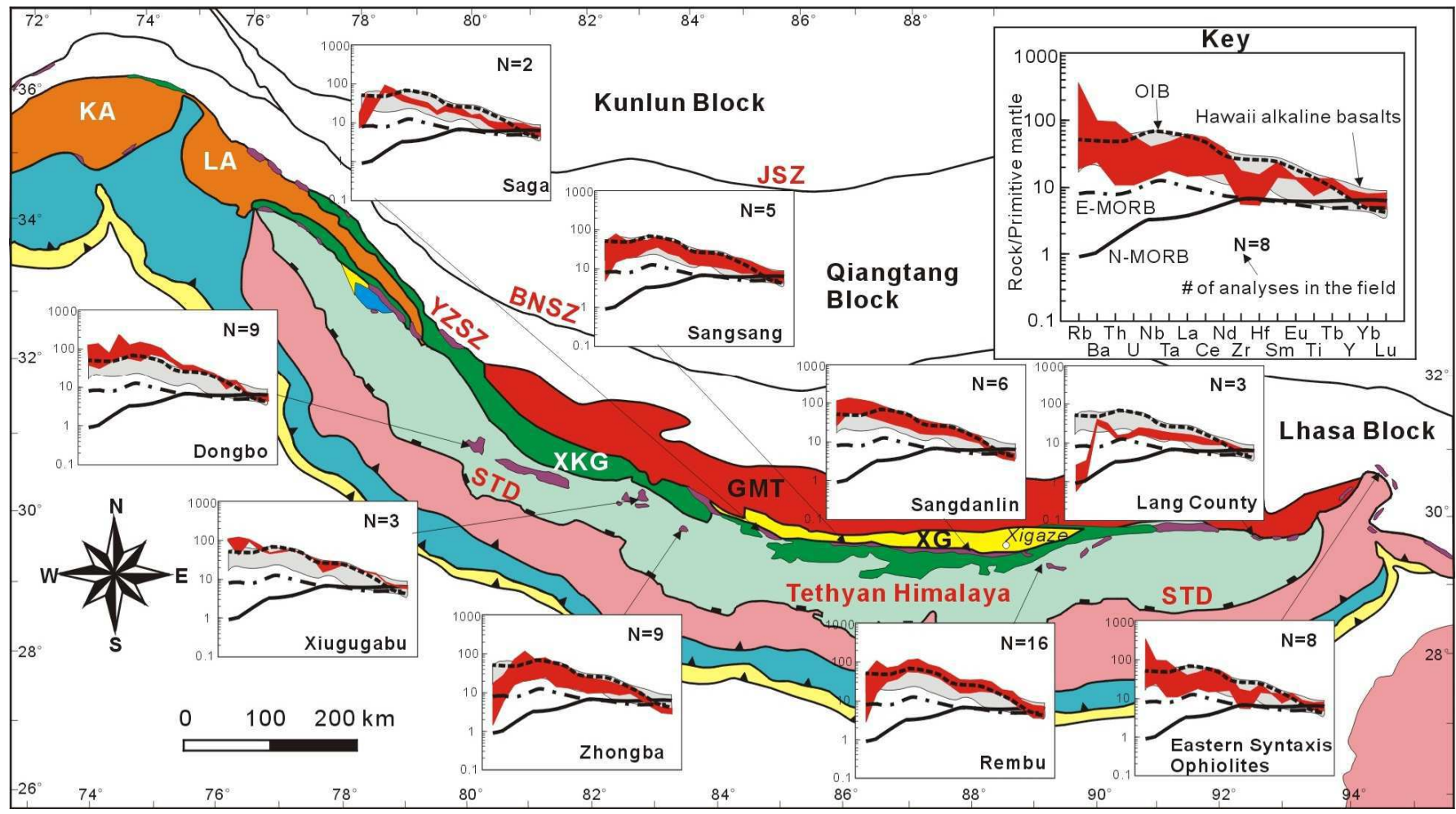

Figure 4. Primitive-mantle-normalized spider diagrams for the OIB-type mafic rocks from the ophiolite massifs investigated in this study. Primitive mantle values, and the N-MORB, E-MORB, and OIB trends are from Sun and McDonough (1989). Data for the Hawaii alkaline basalt field are from Garcia et al. (1995), Hofmann and Jochum (1996), and Xu et al. (2007). Map symbols are the same as in Figure 1. Data sources for the chemical compositions of the OIB-type rocks from different ophiolite massifs are listed in Table 2. 


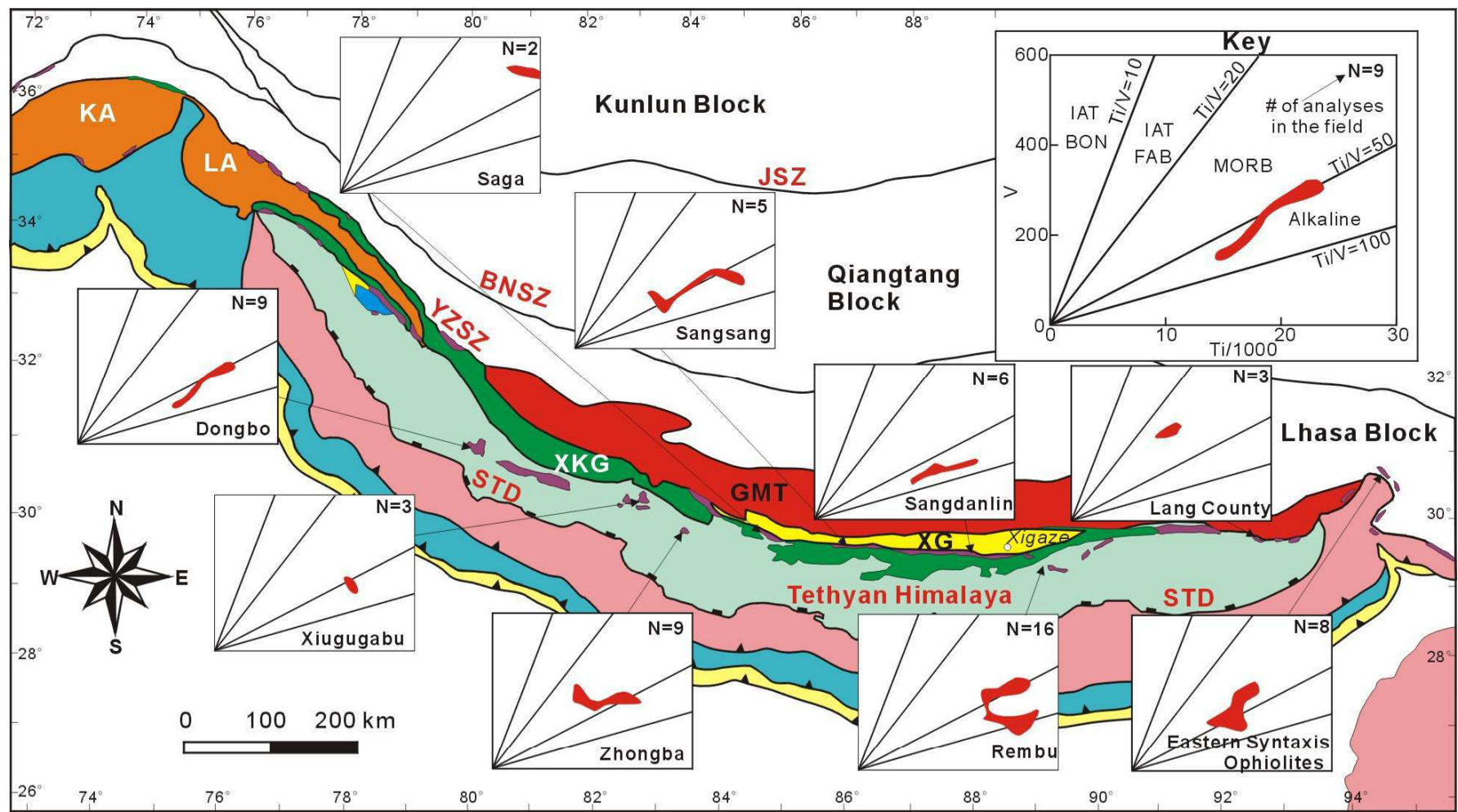

Figure 5. Ti/1000 (ppm) versus V (ppm) diagram (modified after Shervais, 1982) for the OIB-type mafic rocks from the ophiolite massifs investigated in this study. Map symbols are the same as in Figure 1. Data sources for the chemical compositions of the OIB-type rocks from different ophiolite massifs are listed in Table 2.

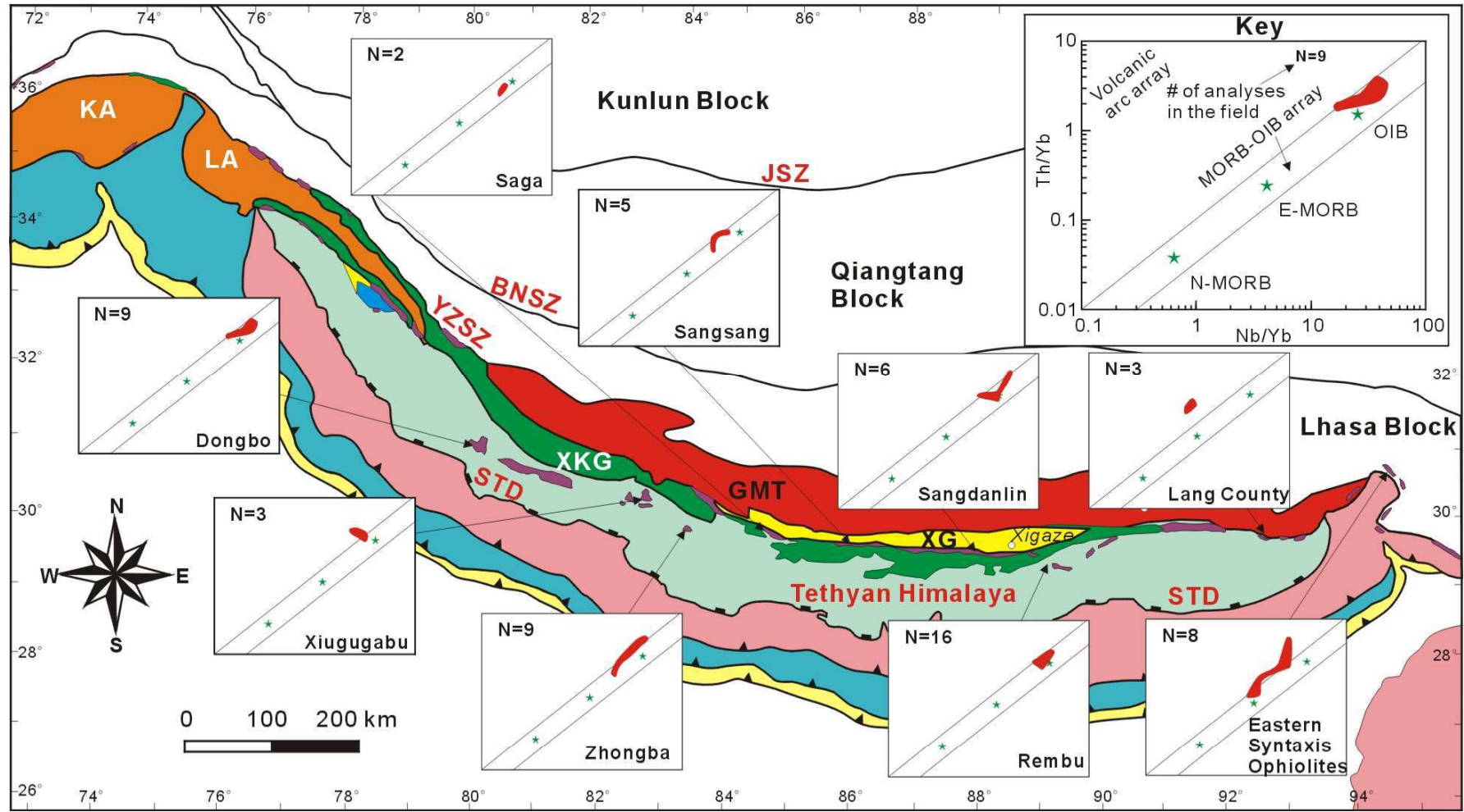

Figure 6. $\mathrm{Th} / \mathrm{Yb}$ vs $\mathrm{Nb} / \mathrm{Yb}$ proxy for the OIB-type mafic rocks from the ophiolite massifs investigated in this study. The MORB-OIB array and the volcanic arc array are from Pearce (2008). Map symbols are the same as in Figure 1. Data sources for the chemical compositions of the OIB-type rocks from different ophiolite massifs are listed in Table 2. The data for the Hawaiian alkaline basalt field are from: Chen et al., 1990; Gaffney et al., 2004; Kimura et al., 2006. 


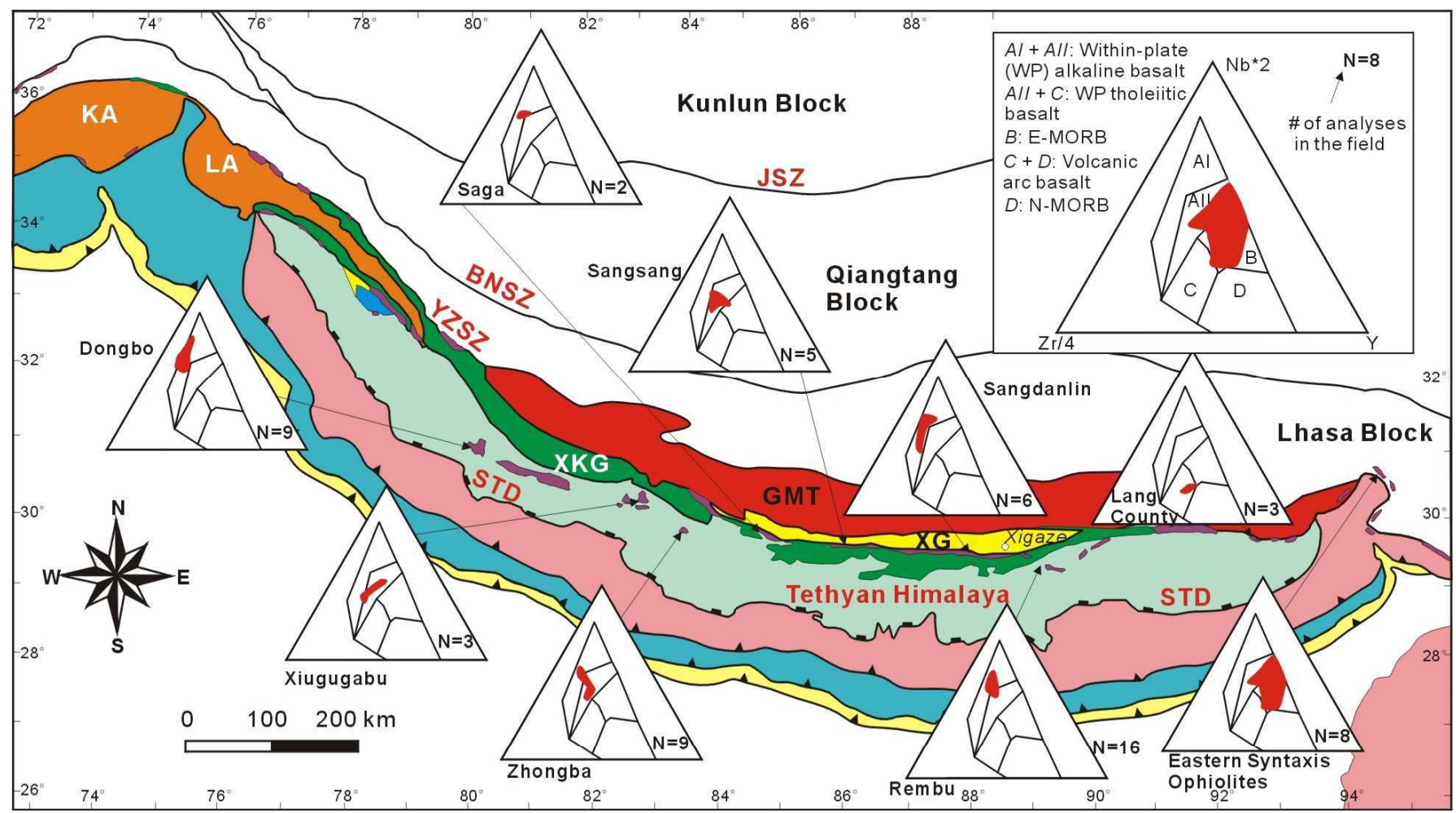

Figure 7. Nb*2-Zr/4-Y triangular diagram for the OIB-type mafic rocks from the ophiolite massifs investigated in this study. Map symbols are the same as in Figure 1. Data sources for the chemical compositions of the OIB-type rocks from different ophiolite massifs are listed in Table 2.
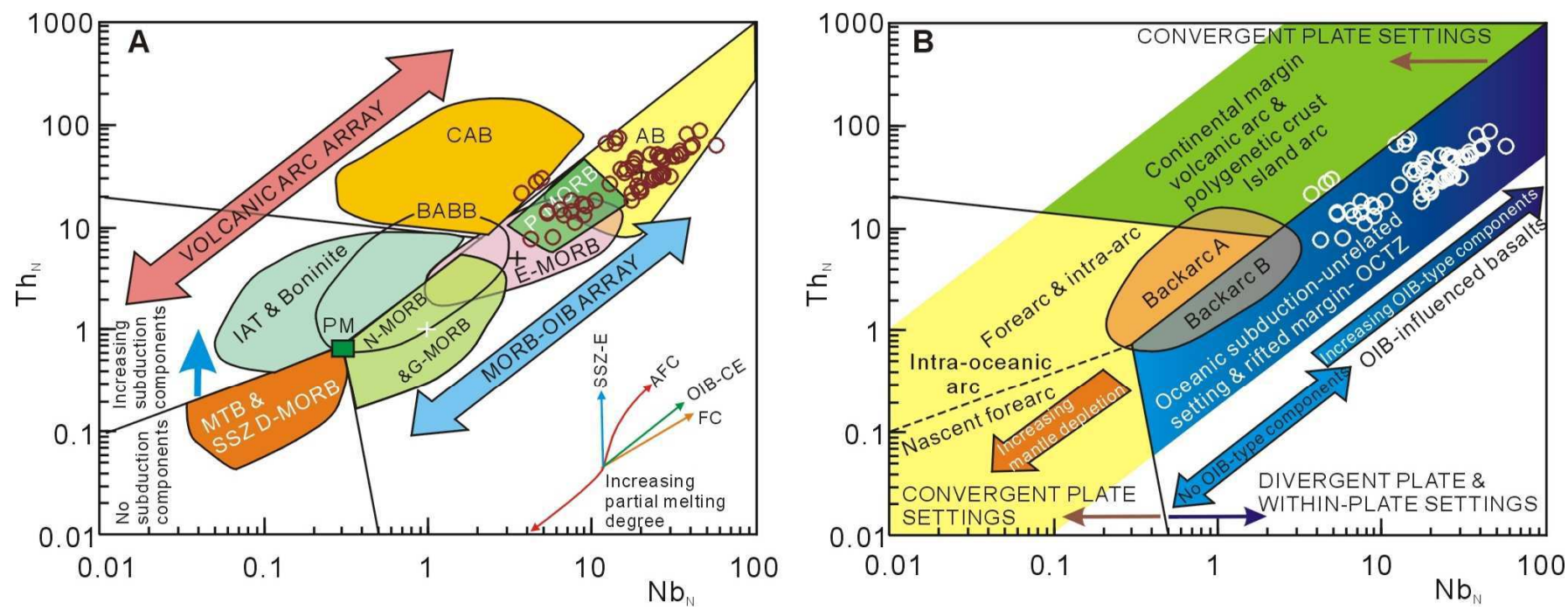

Figure 8: A- N-MORB normalized $T h_{N} v s . N b_{N}$ binary discriminant diagram, showing the compositional variations of different mafic rocktypes and their tectonic affinities (after Saccani, 2015) and the distribution of the representative OIB-type rocks from the YZSZ. Vectors mark the trends of compositional variations controlled by the main petrogenetic processes. Abbreviations for vectors: SSZ-E: supra-subduction zone enrichment; AFC: assimilation-fractional crystallization; OIB-CE: ocean island-type (plume-type) component enrichment; FC: fractional crystallization. Crosses represent the compositions of typical N-MORB, E-MORB and OIB (after Sun and McDonough, 1989). Key for other symbols: MORB - mid-ocean ridge basalt; G-MORB - garnet-influenced MORB; N-MORB - normal-type MORB; E-MORB - enriched-type MORB; P-MORB - plume-type MORB; AB - alkaline ocean island basalt; IAT - low-Ti, island arc tholeiite; BON - very low-Ti, boninitic basalt; CAB - calc-alkaline basalt; MTB - medium-Ti basalt; D-MORB - depleted-type MORB; BABB - backarc basin basalt. B-Tectonic interpretation of ophiolitic mafic rock types based on $\mathrm{Th}_{N}{ }^{-N b_{N}}$ systematics, and the distribution of the representative OIB-type rocks from the YZSZ. Backarc A - backarc basin basalts (BABB) characterized by input of subduction or crustal components; Backarc B-BABBs with no input of subduction or crustal components (mature intra-oceanic back arcs); OCTZ - ocean-continent transition zone. See text for further discussion. 
A $S$
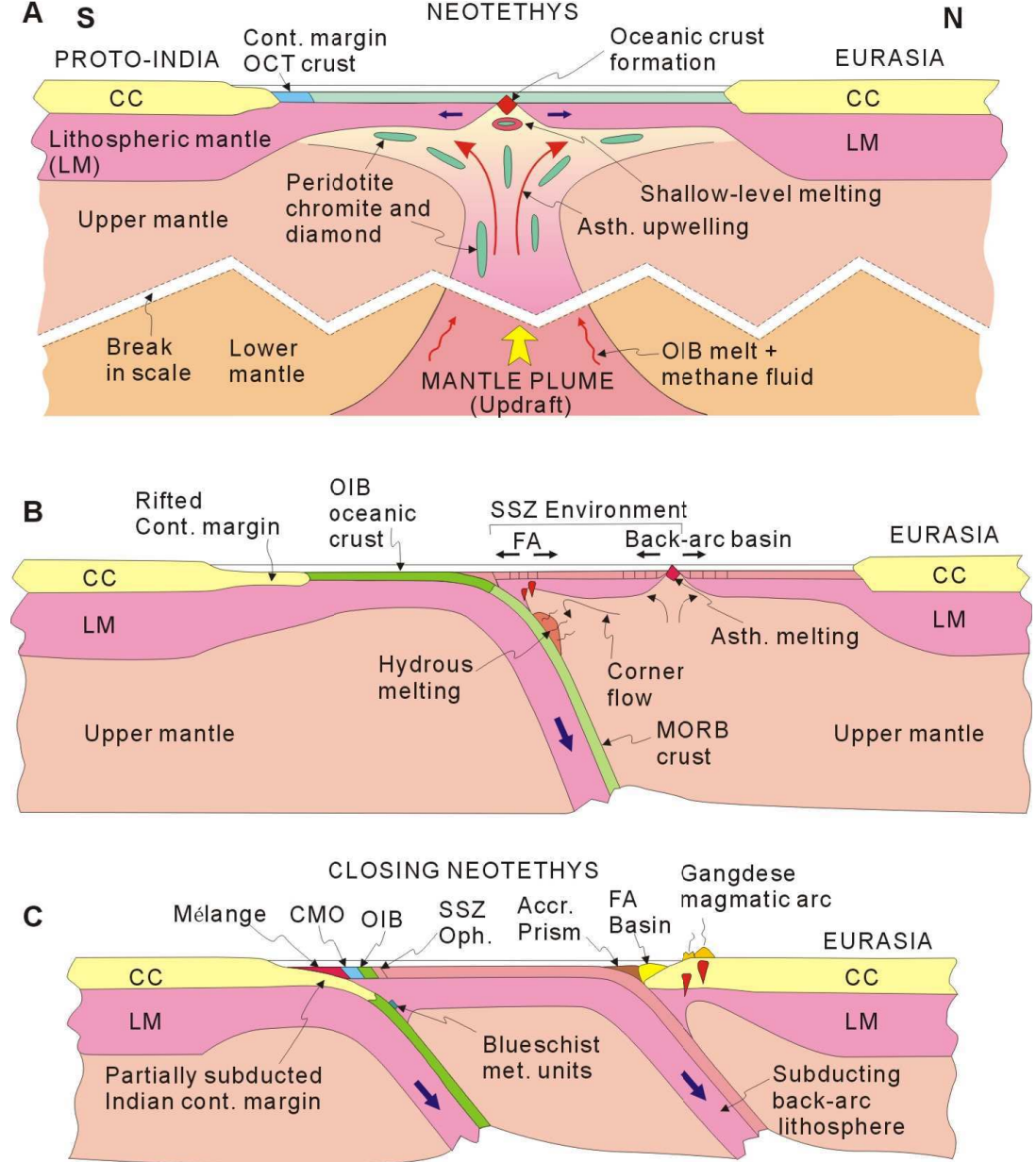

Figure 9: Sequential tectonic model for the evolution of the YZSZ ophiolites and the associated P-type and OIB-type mafic rock assemblages (modified after Xu et al., 2015a). See text for discussion. Key for symbols: CC - Continental crust; CMO Continental margin ophiolite; FA - Forearc; OCT - Ocean-continent transition; LM - Lithospheric mantle; OIB - Ocean Island Basalt.

fluids might have contributed to the carbon budget in the transition zone and have acted as catalysts for diamond crystallization.

The younger Neotethyan oceanic crust (130-120 Ma) preserved within the YZSZ include mafic-ultramafic rock units that display strong subduction influence in their melt evolution. These subductionrelated YZSZ ophiolites formed in forearc to backarc tectonic environments in a suprasubduction zone setting (Hébert et al., 2012; Dai et al., 2013) above a N-dipping, intraoceanic subduction zone during the early Cretaceous (Fig. 9B). The pre-existing oceanic lithosphere that formed via seafloor spreading within the Neotethyan seaway (>170-140 Ma) was consumed at this intraoceanic subduction zone, and the younger SSZ ophiolites (130-120 Ma) were produced through a combination of hydrous melting, corner flow, and slab rollback-driven extensional tectonics in the upper plate. This scenario has been also proposed for the younger (late Cretaceous: 95-92 Ma) Neotethyan ophiolites farther west in the eastern Mediterranean region (Dilek and Flower, 2003; Flower and Dilek, 2003). Tectonic underplating and partial subduction of the northern passive margin of Proto-India beneath the intraoceanic arc system resulted in the telescoping of the SSZ ophiolites and the ophiolitic mélange unit in a stack of S-vergent thrust nappes (Fig. 9C) on top of the continental crust (Tethyan Himalaya) in the lower plate. This arc-continent collision within the Neotethyan realm was instrumental in the initiation of an Andean type convergent margin tectonics along the southern edge of Eurasia that produced the Gangdese magmatic arc and the Xigaze forearc basin in the upper plate, while consuming the backarc generated Neotethyan oceanic lithosphere (Fig. 9C).

\section{Conclusions}

A systematic review of the extant geochemical and geochronological data from the YZSZ ophiolites reveals the widespread occurrence of OIB-type and alkaline mafic rock assemblages, which range in age from the earliest Jurassic through early Cretaceous. These rock associations are tectonically intercalated with oceanic rocks both in the ophiolites and ophiolitic mélanges within the YZSZ, or they occur as blocks and thrust sheets within the Jurassic-Cretaceous flysch units structurally below and south of the YZSZ. They display LREE enrichment and HREE depletion, no subduction influence in their trace element patterns, and significant enrichment in LILE in comparison to HFSE and HREE. Compositionally, they resemble modern OIB and the Hawaiian alkaline basalts. Magmas of these OIB-type and alkaline rock associations formed from partial melting of a MORBtype asthenospheric source, enriched by plume component, during the rift-drift and seafloor spreading evolution of the Neotethyan oceanic lithosphere during the Jurassic through Cretaceous. The younger (130-120 Ma) oceanic lithosphere evolved in forearc to backarc SSZ settings above a N-dipping subduction zone, which consumed much of the previously formed Neotethyan oceanic crust. The YZSZ ophiolites hence reflect a poly-phase melt history and different mantle melt sources in their evolutionary history. Tectonic juxtaposition of the geochemically and geochronologically diverse Neotethyan ophiolites took place during their emplacement onto the northern passive margin of Proto-India in the lower plate during the late Cretaceous. The existence within the YZSZ and the suture zones in other Tethyan orogenic belts of OIB-type and alkaline mafic rocks shows that oceanic rocks produced during different stages of the Wilson cycle evolution of ocean basins are commonly well preserved in the crustal architecture of the collision zones (Dilek and Sandvol, 2009).

\section{Acknowledgements}

This research was financially supported by the National Nature Science Foundation of China (41303027), and Special Fund for Basic Scientific Research of Central Colleges, Chang'an University (310827153506, 310827153407) to G.-X. Yang. Y. Dilek's research in Tibet and on the Yarlung-Zangbo suture zone ophiolites has been funded by the Chinese Academy of Geological Sciences (Beijing, China). We thank R. Hébert, J.S. Yang, Z.Q. Xu, and F. Liu for insightful discussions on the geology, geochemistry and structure of the Yarlung-Zangbo ophiolites and on various aspects of our study as presented in this paper. 


\section{References}

Ahmad, T., Tanaka, T., Sachan, H.K., Isalm, R., and Khanna, P.P., 2008, Geochemical and isotopic characteristics of the gabbroic rocks from Nidar ophiolitic complex, Indus Suture Zone, Eastern Ladakh. National Symposium on Milestones in Petrology. Banaras Hindu University and Geological Society of India, Varanasi, pp. 57.

Aitchison, J.C., Davis, A.M., Liu, J., Luo, H., Malpas, J.G., McDermid, I.R.C., Wu, H.Y., Ziabrev, S.V., and Zhou, M.F., 2000, Remnants of a Cretaceous intra-oceanic subduction system within the Yarlung-Zangbo suture (southern Tibet). Earth and Planetary Science Letters, v. 183, pp. 231244.

Allègre, C.J., Courtillot, V., Tapponnier, P., Hirn, A., Mattauer, M., Coulon, C., Jaeger, J.J., Achache, J., Schärer, U., Marcoux, J., Burg, J.P., Girardeau, J., Armijo, R., Gariépy, C., Göpel, C., Li, T.D., Xiao, X.C., Chang, C.F., Li, G.Q., Lin, B.Y., Teng, J.W., Wang, N.W., Chen, G.M., Han, T.L., Wang, X.B., Den, W.M., Sheng, H.B., Cao, Y.G., Zhou, J., Qiu, H.R., Bao, P.S., Wang, S.C., Wang, B.X., Zhou, Y.X., and Xu, R.H., 1984, Structure and evolution of the Himalaya-Tibet orogenic belt. Nature, v. 307, pp. 17-22.

Bao, P.S., Su, L., Wang, J., and Zhai, Q.G., 2014, Origin of the Zedang and Luobuso ophiolites, Tibet. Acta Geological Sinica, v. 88, p. 669-698

Bao, P.S., Su, L., Wang, J., and Zhai, Q.G., 2013, Study on the tectonic setting for the ophiolites in Xigaze, Tibet. Acta Geologica Sinica-English Edition, v. 87 , pp. $395-425$.

Bédard, É., Hébert, R., Guilmette, C., Lesage, G., Wang, C.S., and Dostal, J., 2009, Petrology and geochemistry of the Saga and Sangsang ophiolitic massifs, Yarlung Zangbo Suture Zone, Southern Tibet: Evidence for an arc-back-arc origin. Lithos, v. 113, pp. 48-67.

Bezard, R., Hébert, R., Wang, C.S., Dostal, J., Dai, J.G., and Zhong, H.T., 2011, Petrology and geochemistry of the Xiugugabu ophiolitic massif, western Yarlung Zangbo suture zone, Tibet. Lithos, v. 125, pp. 347-367.

Buiter, S.J.H and Torsvik, T.H., 2014, A review of Wilson Cycle plate margins: A role for mantle plumes in continental break-up along sutures? Gondwana Research, v. 26, p. 627-653.

Burg, J.P., and Chen, G.M., 1984, Tectonic and structural zonation of southern Tibet, China. Nature, v. 311, pp. 219-223.

Chan, G.H.N., Crowley, Q., Searle, M., Aitchison, J.C., and Horstwood, M., 2007, U-Pb zircon ages of the Yarlung Zangbo suture zone ophiolites, south Tibet, 22th Himalaya-Karakorum-Tibet Workshop, Hong Kong, China. Workshop Abstract Volume 12.

Chan, G.H.N., Aitchison, J.C., Crowley, Q., Horstwood, M., Searle, M.P., Parrish, R.R., and Chan, J.S.L., 2015, U-Pb zircon ages for Yarlung Tsangpo suture zone ophiolites, southwestern Tibet and their tectonic implications. Gondwana Research, v. 27, pp. 719-732.

Chen, C., Frey, F., and Garcia, M., 1990, Evolution of alkalic lavas at Haleakala Volcano, east Maui, Hawaii. Contributions to Mineralogy and Petrology, v. 105 , pp. $197-218$.

Chen, G.W., and Xia, B., 2008. Platinum-group elemental geochemistry of mafic and ultramafic rocks from the Xigaze ophiolite, southern Tibet. Journal of Asian Earth Sciences, v. 32, pp. 406-422.

Chu, M.F., Chung, S.L., Song, B.A., Liu, D.Y., O'Reilly, S.Y., Pearson, N.J., Ji, J.Q., and Wen, D.J., 2006, Zircon U-Pb and Hf isotope constraints on the Mesozoic tectonics and crustal evolution of southern Tibet. Geology, v. 34, pp. 745-748.

Chung, S.L., Chu, M.F., Zhang, Y.Q., Xie, Y.W., Lo, C.H., Lee, T.Y., Lan, C.Y., Li, X.H., Zhang, Q., and Wang, Y.Z., 2005, Tibetan tectonic evolution inferred from spatial and temporal variations in post-collisional magmatism. Earth-Science Reviews, v. 68, pp. 173-196.

Dai, J., Wang, C., Hébert, R., Li, Y., Zhong, H., Guillaume, R., Bezard, R., and Wei, Y., 2011a, Late Devonian OIB alkaline gabbro in the Yarlung Zangbo Suture Zone: Remnants of the Paleo-Tethys? Gondwana Research, v. 19 , pp. 232-243

Dai, J.G., Wang, C.S., Hébert, R., Santosh, M., Li, Y.L., and Xu, J.Y., 2011b,
Petrology and geochemistry of peridotites in the Zhongba ophiolite, Yarlung Zangbo Suture Zone: Implications for the early Cretaceous intraoceanic subduction zone within the Neo-Tethys. Chemical Geology, v. 288, pp. $133-148$.

Dai, J., Wang, C., and Li, Y., 2012, Relicts of the Early Cretaceous seamounts in the central-western Yarlung Zangbo Suture Zone, southern Tibet. Journal of Asian Earth Sciences, v. 53, pp. 25-37.

Dai, J., Wang, C., Polat, A., Santosh, M., Li, Y., and Ge, Y., 2013, Rapid forearc spreading between 130-120 Ma: evidence fromgeochronology and geochemistry of the Xigaze ophiolite, southern Tibet. Lithos, v. 172173, pp. 1-16.

Dilek, Y., 2003, Ophiolite pulses, mantle plumes and orogeny. In, Geological Society, London, Special Publications, v. 218, pp. 9-19.

Dilek, Y., and Flower, M.F.J., 2003, Arc-trench rollback and forearc accretion: 2. Model template for Albania, Cyprus, and Oman In, Geological Society of London Special Publications, v. 218, p. 43-68.

Dilek, Y., and Newcomb, S., 2003, Ophiolite concept and the evolution of geological thought. Geological Society of America Special Papers, v. 373, The Geological Society of America, Boulder, CO 80301, ISBN 0-8137-2373-6.

Dilek, Y. and Robinson, P.T., 2003. Ophiolites in Earth History: Introduction: Geological Society, London, Special Publication, v. 218, pp. 1-8, doi: 10.1144/gsl.sp.2003.218.01.01

Dilek, Y., and Furnes, H., 2009, Structure and geochemistry of Tethyan ophiolites and their petrogenesis in subduction rollback systems. Lithos, v. 113, pp. 1-20.

Dilek, Y., and Furnes, H., 2011, Ophiolite genesis and global tectonics: Geochemical and tectonic fingerprinting of ancient oceanic lithosphere. Geological Society of America Bulletin, v. 123, pp. 387-411.

Dilek, Y., and Furnes, H., 2014, Ophiolites and Their Origins. Elements, v. 10 , pp. 93-100.

Dilek, Y., Furnes, H., and Shallo, M., 2008, Geochemistry of the Jurassic Mirdita Ophiolite (Albania) and the MORB to SSZ evolution of a marginal basin oceanic crust. Lithos, v. 100, pp. 174-209.

Dilek, Y., and Thy, P., 1998, Structure, petrology and seafloor spreading tectonics of the Kizildag ophiolite, Turkey. Geological Society, London, Special Publications, v. 148, p. 43-69.

Dilek, Y. and Sandvol, E., 2009, Seismic structure, crustal architecture and tectonic evolution of the Anatolian-African plate boundary and the Cenozoic orogenic belts in the Eastern Mediterranean region. Geological Society, London, Special Publications, v. 329, pp. 127-160, doi: doi:10.1144/SP327.8

Dubois-Côté, V., Hébert, R., Dupuis, C., Wang, C.S., Li, Y.L., and Dostal, J., 2005, Petrological and geochemical evidence for the origin of the Yarlung Zangbo ophiolites, southern Tibet. Chemical Geology, v. 214, pp. 265286.

Dupuis, C., Hébert, R., Dubois-Côté, V., Wang, C.S., Li, Y.L., and Li, Z.J., 2005, Petrology and geochemistry of mafic rocks from melange and flysch units adjacent to the Yarlung Zangbo Suture Zone, southern Tibet. Chemical Geology, v. 214, pp. 287-308.

Einsele, G., Liu, B., Duerr, S., Frisch, W., Liu, G., Luterbacher, H.P., Ratschbacher, L., Richen, W., Wendt, J., Wetzel, A., Yu, G., Zheng, H., 1994, The Xigaze forearc basin: evolution and facies architecture (Cretaceous, Tibet). Sedimentary Geology, v. 90, pp. 1-32.

Fareeduddin and Dilek, Y., 2015, Structure and Petrology of the Nagaland-Manipur Hill Ophiolite Melange Zone, NE India: A Fossil Tethyan Subduction Channel at the Indo-Myanmar Plate Boundary. Episodes, v. 38, No.4, pp. 298-314, doi: 10.18814/epiiugs/2015/v38i4/ 82426.

Flower, M.F.J. and Dilek, Y., 2003, Arc-trench rollback and forearc accretion: 1. A collision-induced mantle flow model for Tethyan ophiolites: In, Geological Society of London Special Publications, v. 218, p. 21-42.

Gaffney, A., Nelson, B., and Blichert-Toft, J., 2004, Geochemical constraints on the role of oceanic lithosphere in intra-volcano heterogeneity at West Maui. Hawaii. Journal of Petrology, v. 45, pp. 1663-1687.

Garcia, M.O., Foss, D.J.P., West, H.B., and Mahoney, J.J., 1995, Geochemical 
and isotopic evolution of Loihi volcano, Hawaii. Journal of Petrology, v. 36, pp. $1647-1674$.

Geng, Q.R., Pan, G.T., Zheng, L.L., Chen, Z.L., Fisher, R.D., Sun, Z.M., Ou, C.S., Dong, H., Wang, X.W., Li, S., Lou, X.Y., and Fu, H., 2006, The eastern Himalayan syntaxis: major tectonic domains, ophiolitic mélanges and geologic evolution. Journal of Asian Earth Sciences, v. 27, pp. 265285.

Geng, Q.R., Peng, Z.M., and Zhang, Z., 2010, Geochemical study on metamorphosed mafic rocks in ophiolitic zone in the Yarlung Zangbo Great Bend, eastern Tibet, China. Geological Bulletin of China, v. 29, pp. 1781-1794.

Ghose, N.C., Chatterjee, N., and Fareeduddin, 2014, A petrographic atlas of ophiolite: An example from the Eastern India - Asia collision zone. Springer Science, pp. 234.

Göpel, C., Allègre, C.J., and Xu, R.H., 1984, Lead isotopic study of the Xigaze ophiolite (Tibet): the problem of the relationship between magmatites (gabbros, dolerites, lavas) and tectonites (harzburgites). Earth and Planetary Science Letters, v. 69, pp. 301-310.

Goscombe, B., Gray, D., and Hand, M., 2006, Crustal architecture of the Himalayan metamorphic front in eastern Nepal. Gondwana Research, v. 10, pp. $232-255$

Guilmette, C., Hébert, R., Bédard, É., Wang, C.S., Ullrich, T.D., and Dostal, J., 2007, Saga ophiolite, Yarlung Zangbo suture Zone, Tibet: field relationships, discovery of garnet-pyroxene amphibolite and $\mathrm{Ar} / \mathrm{Ar}$ ages. Workshop Abstract Volume, HKTW 22 Hong Kong, pp. 37.

Guilmette, C., Hébert, R., Dostal, J., Indares, A., Ullrich,T., Bédard, E., and Wang, C.S., 2012, Discovery of a dismembered metamorphic sole in the Saga ophiolitic mélange, South Tibet: Assessing an Early Cretaceous disruption of the Neo-Tethyan supra-subduction zone and consequences on basin closing. Gondwana Research, v. 22, pp. 398-414.

Guilmette, C., Hébert, R., Dupuis, C., Wang, C.S., and Li, Z.J., 2008, Metamorphic history and geodynamic significance of high-grade metabasites from the ophiolitic mélange beneath the Yarlung Zangbo ophiolites, Xigaze area, Tibet. Journal of Asian Earth Sciences, v. 32, pp. 423-437.

Guilmette, C., Hébert, R., Wang, C., and Villeneuve, M., 2009, Geochemistry and geochronology of the metamorphic sole underlying the Xigaze Ophiolite, Yarlung Zangbo Suture Zone, South Tibet. Lithos, v. 112, pp. 149-162.

Hébert, R., Bezard, R., Guilmette, C., Dostal, J., Wang, C.S., and Liu, Z.F., 2012, The Indus-Yarlung Zangbo ophiolites from Nanga Parbat to Namche Barwa syntaxes, southern Tibet: First synthesis of petrology, geochemistry, and geochronology with incidences on geodynamic reconstructions of Neo-Tethys. Gondwana Research, v. 22, pp. 377-397.

Hébert, R., Huot, F., Wang, C.S., and Liu, Z., 2003, Yarlung Zangbo ophiolites, southern Tibet revisited: geodynamic implications from the mineral record. In: Dilek, Y., Robinson, P.T. (Eds.), Ophiolites in Earth History: Special Publication, 218. The Geological Society of London, London, pp. $165-190$.

Hofmann, A., and Jochum, K., 1996, Source characteristics derived from very incompatible trace elements in Mauna Loa and Mauna Kea basalts, Hawaii Scientific Drilling Project. Journal of Geophysical Research, v. 101, pp. 831-839.

Honneger, K., Dietrich, V., Frank, W., Gansser, A., Thoni, M., and Trommsdorf, V., 1982, Magmatic and metamorphism in the Ladakh Himalayas (the Indus-Tsangpo suture zone). Earth and Planetary Science Letters, v. 60, pp. 253-292.

Huang, Y.H., Zhon, X.Z., and Wang, X.B., 1981, Pumpellyite from the contact metamorphic zone of ultramafic bodies of Luobusa ophiolite suite, South Tibet. Bulletin de Mineralogie, v. 104, pp. 441-444.

Huot, F., Hébert, R., Varfalvy, V., Beaudoin, G., Wang, C.S., Liu, Z.F., Cotten, J., and Dostal, J., 2002, The Beimarang melange (southern Tibet) brings additional constraints in assessing the origin, metamorphic evolution and obduction processes of the Yarlung Zangbo ophiolite. Journal of Asian Earth Sciences, v. 21, pp. 307-322.

Ji, W.Q., Wu, F.Y., Chung, S.L., Li, J.X., and Liu, C.Z., 2009, Zircon U-Pb geochronology and $\mathrm{Hf}$ isotopic constraints on petrogenesis of the Gangdese batholith, southern Tibet. Chemical Geology, v. 262, pp. 229245.

Kimura, J., Sisson, T., Nakano, N., Coombs, M., and Lipman, P., 2006, Isotope geochemistry of early Kilauea magmas from the submarine Hilina bench: The nature of the Hilina mantle component. Journal of Volcanology and Geothermal Research, v. 151, pp. 51-72.

Kojima, S., Ahmad, T., Tanaka, T., Bagati, T.N., Mishra, M., Kumar, R., Islam, R., and Khanna, P., 2001, Early Cretaceous radiolarians from the Indus suture zone, Ladakh, northern India. News of Osaka Micropaleontologists, v. 12, pp. 257-270.

Li, J.F., Xia, B., Liu, L.W., Xu, L.F., He, G.S., Wang, H., Zhang, Y.Q., and Yang, Z.Q., 2008, SHRIMP U-Pb zircon dating of diabase in the La'nga Co ophiolite, Burang, Tibet, China, and its geological significance. Geological Bulletin of China, v. 27, pp. 1739-1743.

Li, J.F., Xia, B., Liu, L.W., Xu, L.F., He, G.S., Wang, H., Zhang, Y.Q., and Yang, Z.Q., 2009, SHRIMP U-Pb dating for the Gabbro in Qunrang Ophiolite, Tibet: the geochronology constraint for the development of eastern Tetys basin. Geotectonica et Metallogenia, v. 33, pp. 294-298.

Liang, F.H., Xu, Z.Q., Ba, D.Z., Xu, X.Z., Liu, F., Xiong, F.H., and Jia, Y., 2011, Tectonic occurrence and emplacement mechanism of ophiolite from Luobusha-Zedang, Tibet. Acta Petrologica Sinica, v. 27, pp. 3255-3268.

Liu, C.Z., Wu, F.Y., Wilde, S.A., Yu, L.J., and Li, J.L., 2010, Anorthitic plagioclase and pargasitic amphibole in mantle peridotites from the Yungbwa ophiolite (southwestern Tibetan Plateau) formed by hydrous melt metasomatism. Lithos, v. 114, pp. 413-422.

Liu, C.Z., Wu, F.Y., Chu, Z.Y., Ji, W.Q., Yu, L.J., and Li, J.L., 2012, Preservation of ancient Os isotope signatures in the Yungbwa ophiolite (southwestern Tibet) after subduction modification. Journal of Asian Earth Sciences, v. 53, pp. 38-50.

Liu, F., Yang, J.S., Chen, S.Y., Liang, F.H., Niu, X.L., Li, Z.L., and Lian, D.Y., 2013, Ascertainment and environment of the OIB-type basalts from the Dongbo ophiolite in the western part of Yarlung Zangbo Suture Zone. Acta Petrologica Sinica, v. 29, pp. 1909-1932.

Liu, F., Yang, J.S., Dilek, Y., Xu, Z.Q., Xu, X.Z., Liang, F.H., Chen, S.Y., and Lian, D.Y., 2015, Geochronology and geochemistry of basaltic lavas in the Dongbo and Purang ophiolites of the Yarlung-Zangbo Suture zone: Plume-influenced continental margin-type oceanic lithosphere in southern Tibet. Gondwana Research, v. 27, pp. 701-718.

Mahéo, G., Bertrand, H., Guillot, S., Villa, I.M., Keller, F., and Capiez, P., 2004, The south Ladakh ophiolites (NW Himalaya, India): an intraoceanic tholeiitic origin with implication for the closure of the Neo-Tethys. Chemical Geology, v. 203, pp. 273-303.

Malpas, J., Zhou, M.F., Robinson, P.T., and Reynolds, P.H., 2003, Geochemical and geochronological constraints on the origin and emplacement of the Yarlung Zangbo ophiolites, Southern Tibet. In: Dilek, Y., Robinson, P.T. (Eds.), Ophiolites in Earth History. Geological Society, London, Special Publications, v. 218, pp. 191-206.

McDermid, I., Aitchison, J., Davis, A., Harrison, T., and Grove, M., 2002, The Zedong terrane: a Late Jurassic intra-oceanic magmatic arc within the Yarlung-Tsangpo suture zone, southeastern Tibet. Chemical Geology, v. 187 , pp. $267-277$.

Meschede, M., 1986, A method of discriminating between different types of mid-ocean ridge basalts and continental tholeiites with the $\mathrm{Nb}-\mathrm{Zr}-\mathrm{Y}$ diagram. Chemical Geology, v. 56, pp. 207-218.

Miller, C., Thöni, M., Frank, W., Schuster, R., Melcher, F., Meisel, T., Zanetti, A., 2003, Geochemistry and tectonomagmatic affinity of the Yungbwa ophiolite, SW Tibet. Lithos, v. 66, pp. 155-172.

Parkinson, I.J., and Pearce, J.A., 1998, Peridotites from the Izu-BoninMariana Forearc (ODP Leg 125), Evidence for mantle melting and meltmantle interaction in a supra-subduction zone setting. Journal of Petrology, v. 39, pp. 1577-1618.

Pearce, J., 2008, Geochemical fingerprinting of oceanic basalts with applications to ophiolite classification and the search for Archean oceanic crust. Lithos, v. 100, pp. 14-48.

Pedersen, R.B., Searle, M.P., and Corfield, R.I., 2001, U-Pb zircon ages 
fromthe Spontang Ophiolite, Ladakh Himalaya. Journal of the Geological Society of London, v. 158, pp. 513-520.

Reuber, I., Colchen, M., and Mevel, C., 1987, The geodynamic evolution of the South-Tethyan margin in Zanskar, NW Himalaya, as revealed by the Spongtang ophiolitic melange. Geodinamica Acta, v. 1, pp. 283-296.

Reuber, I., Montigny, R., Thuizat, R., and Heitz, A., 1989, K-Ar ages of ophiolites and arc volcanics of the Indus Suture Zone: comparison with other Himalaya-Karakorum data. Eclogae Geologicae Helvetiae, v. 82, pp. 699-715.

Robinson, P.T., Bai, W.J., Malpas, J., Yang, J.S., Zhou, M.F., Fang, Q.S., Hu, X.F., Cameron, S., and Staudigel, H., 2004, Ultra-high pressure minerals in the Luobusa Ophiolite, Tibet, and their tectonic implications. In: Malpas, J., Fletcher, C.J.N., Ali, J., Aitchison, J.C. (Eds.), Aspects of the Tectonic Evolution of China: Geological Society of London Special Publications, v. 226, pp. 247-271.

Saccani, E., 2015, A new method of discriminating different types of postArchean ophiolitic basalts and their tectonic significance using Th-Nb and Ce-Dy-Yb systematics. Geoscience Frontiers, v. 6, pp. 481-501.

Saccani, E., Dilek, Y., Marroni, M., and Pandolfi, L., 2015, Continental margin ophiolites of Neotethys: Remnants of ancient Ocean-Continent Transition Zone (OCTZ) lithosphere and their geochemistry, mantle sources and melt evolution patterns. Episodes, v. 38, No. 4, pp. 230-249, doi: 10.18814/epiiugs/2015/v38i4/82418.

Shi, R.D., Alard, O., Zhi, X.C., O’Reilly, S.Y., Pearson, N.J., Griffin, W.L., Zhang, M., and Chen, X.M., 2007, Multiple events in the Neo-Tethyan oceanic upper mantle: Evidence from Ru-Os-Ir alloys in the Luobusa and Dongqiao ophiolitic podiform chromitites, Tibet. Earth and Planetary Science Letters, v. 261, pp. 33-48.

Shervais, J.W., 1982, Ti-V plots and the petrogenesis of modern and ophiolitic lavas. Earth and Planetary Science Letters, v. 59, pp. 101-118.

Sihna, A.K., and Mishra, M., 1997, India-Eurasia tectonics, evidence of Cretaceous oceanic basalts along the ophiolitic mélange belt of Ladakh Himalaya, India. In: Sassi, F.P., Papnikolaou, D. (Eds.), Geodynamic Domains in the Alpine-Himalaya Tethys. Osford and IBH Publishing, New Delhi. pp 441.

Sun, L.X., Wan, X.Q., Wu, X.G., Jia, J.C., and Gao, L.F., 2005, Geochemical characteristics of basalt in a mélange zone in the central segment of the Yarlung Zangbo juncture. Geological bulletin of China, v. 24, pp. 6571.

Sun, S.S., and McDonough, W.F., 1989, Chemical and isotopic systematic of oceanic basalts: implications for mantle composition and processes. In: Saunder, A.D., Norry, M.J. (Eds.), Magmatism in the Ocean Basins: The Geological Society of London, Special Publication, v. 42, pp. 313-345.

Wang, C.S., Liu, Z.F., and Hébert, R., 2000, The Yarlung-Zangbo paleoophiolite, southern Tibet: implications for the dynamic evolution of the Yarlung-Zangbo Suture Zone. Journal of Asian Earth Sciences, v. 18, pp. 651-661.

Wang, C.S., Liu, Z.F., Li, X.H., and Wan, X.Q., 1999. Xigaze Forearc Basin and Yarlung-Zangbo Suture Zone, Tibet. Beijing Geological Publishing House, China, pp. 237.

Wang, C.S., Li, X.H., Liu, Z.F., Li, Y.L., Jansa, L., Dai, J.G., and Wei, Y.S., 2012, Revision of the Cretaceous-Paleogene stratigraphic framework, facies architecture and provenance of the Xigaze forearc basin along the Yarlung Zangbo suture zone. Gondwana Research, v. 22, pp. 415-433.

Wang, R., Xia, B., Zhou, G., Zhang, Y., Yang, Z., Li, W., Wei, D., Zhong, L., and $\mathrm{Xu}, \mathrm{L} ., 2006$, SHRIMP zircon U-Pb dating for gabbro from the Tiding ophiolite in Tibet. Chinese Science Bulletin, v. 51, pp. 1776-1779.

Wei, D.L., Xia, B., Zhou, G.Q., Wang, R., Zhong, L.F., and Wan, S.K., 2006a, Sm-Nd isochron age of Zedang ophiolite in Tibet and its significance. Acta Geoscientica sinica, v. 27, pp. 31-34.

Wei, Z.Q., Xia, B., Zhang, Y.Q., and Wang, R., 2006b, SHRIMP zircon dating of diabase in the Xiugugabu ophiolite in Tibet and its geological implications. Geotectonica et Metallogenia, v. 30, pp. 93-97.

Wen, D.R., Liu, D.Y., Chung, S.L., Chu, M.F., Ji, J.Q., Zhang, Q., Song, B., Lee, T.Y., Yeh, M.W., Lo, C.H., 2008a, Zircon SHRIMP U-Pb ages of the Gangdese Batholith and implications for Neotethyan subduction in southern Tibet. Chemical Geology, v. 252, pp. 191-201.

Wen, D.R., Chung, S.L., Song, B., Iizuka, Y., Yang, H.J., Ji, J., Liu, D., and Gallet, S., 2008b, Late Cretaceous Gangdese intrusions of adakitic geochemical characteristics, SE Tibet: petrogenesis and tectonic implications. Lithos, v. 105, pp. 1-11.

Wilson, M., 1989. Igneous Petrogenesis. Unwin Hyman, London.

Xia, B., Chen, G.W., Wang, R., and Wang, Q., 2008a, Seamount volcanism associated with the Xigaze ophiolite, Southern Tibet. Journal of Asian Earth Sciences, v. 32, pp. 396-405.

Xia, B., Li, J.F., Liu, L.W., Xu, L.F., He, G.S., Wang, H., Zhang, Y.Q., and Yang, Z.Q., 2008b, SHRIMP U-Pb dating for diabase in Sangsang ophiolite, Xizang, China: Geochronological constraint for development of eastern Tethys basin. Geochimica, v. 37, pp. 399-403.

Xia, B., Yu, H.X., Chen, G.W., Qi, L., Zhao, T.P., and Zhou, M.F., 2003, Geochemistry and tectonic environment of the Dazhuka ophiolite in the Yarlung Zangbo suture zone, Tibet. Geochemistry Journal, v. 37, pp. 311-324.

Xiong, F.H., Yang, J.S., Liang, F.H., Ba, D.Z., Zhang, J., Xu, X.Z., Li, Y., and Liu, Z., 2011, Zircon U-Pb ages of the Dongbo ophiolite in the western Yarlung Zangbo suture zone and their geological significance. Acta Petrologica Sinica, v. 27, pp. 3223-3238.

Xiong, F.H., Yang, J.S., Robinson, P.T., Xu, X.Z., Liu, Z., Li, Y., Li, J.Y., and Chen, S.Y., 2014, Origin of podiform chromitite, a new model based on the Luobusa ophiolite, Tibet. Gondwana Research, v. 27, pp. 525-542, doi: 10.1016/j.gr.2014.04.008.

Xu, D.M., Huang, G.C., and Li, Y.J., 2008, Sm-Nd ages and Nd-Sr-Pb isotope signatures of the Xiugugabu ophiolite, southwestern Tibet. Geology in China, v. 35, pp. 429-435

Xu, G., Frey, F., Clague, D., Abouchami, W., Blichert-Toft, J., Cousens, B., and Weisler, M., 2007, Geochemical characteristics of West Molokai shield- and post shield-stage lavas: constraints on Hawaiian plume models. Geochemistry, Geophysics, Geosystems, v. 8, pp. 1-40.

Xu, X.Z., Yang, J.S., Ba, D.Z., Guo, G.L., Robinson, P.T., and Li, J.Y., 2011, Petrogenesis of the Kangjinla peridotite in the Luobusa ophiolite, Southern Tibet. Journal of Asian Earth Sciences, v. 42, pp. 553-568.

Xu, X.Z., Yang, J.S., Robinson, P.T., Xiong, F.H., Ba, D.Z., and Guo, G.L., 2014 , Origin of ultrahigh pressure and highly reduced minerals in podiform chromitites and associated mantle peridotites of the Luobusa ophiolite, Tibet. Gondwana Research, v. 27, pp. 686-700.

Xu, Z.-Q., Dilek, Y., Yang, J.S., Liang, F.H., Liu, F., Ba, D.Z., Cai, Z.H., Li, G.W., Dong, H.W., and Ji, S.C., 2015a, Crustal structure of the IndusTsangpo suture zone and its ophiolites in southern Tibet. Gondwana Research, v. 27, pp. 507-524.

Xu, Z.-Q., Dilek, Y., Cao, H., Yang, J.-S., Robinson, P.T., Ma, C.-Q., Li, H.Q., Jolivet, M., Roger, F., and Chen, X.J., 2015b, Paleo-Tethyan evolution of Tibet as recorded in the East Cimmerides and West Cathaysides. Journal of Asian Earth Sciences, v. 105, p. 320-337.

Yamamoto, H., Yamamoto, S., Kaneko, Y., Terabayashi, M., Komiya, T., Katayama, I., and Iizuka, T., 2007, Imbricate structure of the Luobusa Ophiolite and surrounding rock units, southern Tibet. Journal of Asian Earth Sciences, v. 29, pp. 296-304.

Yamamoto, S., Komiya, T., Hirose, K., and Maruyama, S., 2009, Coesite and clinopyroxene exsolution lamellae in chromites: In-situ ultrahigh-pressure evidence from podiform chromitites in the Luobusa ophiolite, southern Tibet. Lithos, v. 109, pp. 314-322.

Yang, J.S., Robinson, P.T., and Dilek, Y., 2014, Diamonds in Ophiolites. Elements, v. 10, p. 127-130.

Yang, J.S., Dobrzhinetskaya, L., Bai, W.J., Fang, Q.S., Robinson, P.T., Zhang, J.F., and Green H.W., 2007. Diamond- and coesite-bearing chromitites from the Luobusa ophiolite, Tibet. Geology, v. 35, pp. 875-878.

Yang, J.S., Meng, F.C., Xu, X.Z., Robinson, P.T., Dilek, Y., Makeyev, A.B., Wirth, R., Wiedenbeck, M., Cliff, J., 2015a, Diamonds, native elements and metal alloys from chromitites of the Ray-Iz ophiolite of the Polar Urals. Gondwana Research, v. 27, pp. 459-485

Yang, J.S., Robinson, P.T., and Dilek, Y., 2015b, Diamond-bearing ophiolites 
and their geological occurrence. Episodes, v. 38, No. 4, pp. 344-364, doi: 10.18814/epiiugs/2015/v38i4/82430.

Yin, A., 2006. Cenozoic tectonic evolution of the Himalayan orogen as constrained by along-strike variation of structural geometry, exhumation history, and foreland sedimentation. Earth-Science Reviews, v. 76, pp. 1-131.

Yin, A., and Harrison, T.M., 2000, Geological evolution of Tibetan-Himalayan orogen. Annual Review of Earth and Planetary Sciences, v. 28, pp. 211280.

Zhang, W.P., Mo, X.X., Zhu, D.C., Yuan, S.H., and Wang, L.Q., 2011, Chronology and geochemistry on gabbro and basalt of the ophiolite mélange in Lang County, Tibet, China. Journal of Chengdu University of Technology (Science \& Technology Edition), v. 38, pp. 538-548.

Zhang, S.Q., Mahoney, J.J., Mo, X.X., Ghazi, A.M., Milani, L., Crawford, A.J., Guo, T.Y., and Zhao, Z.D., 2005. Evidence for a Widespread Tethyan Upper Mantle with Indian-Ocean-Type Isotopic Characteristics. Journal of Petrology, v. 46, pp. 829-858.

Zhang, K.J., and Tang, X., 2009. Eclogites in the interior of the Tibetan Plateau and their geodynamic implications. Chinese Science Bulletin, v. 54, pp. 2556-2567.

Zhang, Z., Zhao, G., Santosh, M., Wang, J., Dong, X., and Shen, K., 2010, Late Cretaceous charnockite with adakitic affinities from the Gangdese batholith, southeastern Tibet: evidence for Neo-Tethyan mid-oceanic ridge subduction? Gondwana Research, v. 17, pp. 615-631.

Zhong, L.F., Xia, B., Zhou, G.Q., Zhang, Y.Q., Wang, R., Wei, D.L., and Yang, Z.Q., 2006, SHRIMP age determination of Diabase in Luobusa ophiolite, southern Xizang (Tibet). Geological Review, v. 52, pp. 224229.

Zhou, M.F., Robinson, P.T., Malpas, J., Edwards, S.J., and Qi, L., 2005, REE and PGE geochemical constraints on the formation of dunites in the Luobusa ophiolite, Southern Tibet. Journal of Petrology, v. 46, pp. 615-639.

Zhou, M.F., Robinson, P.T., Malpas, J., and Li, Z., 1996, Podiform chromitites in the Luobusa ophiolite (southern Tibet): implications for melt-rock interaction and chromite segregation in the upper mantle. Journal of Petrology, v. 37, pp. 3-21.

Zhou, M.F., Robinson, P.T., Su, B.X., Gao, J.F., Li, J.W., Yang, J.S., and Malpas, J., 2014, Compositions of chromite, associated minerals, and parental magmas of podiform chromite deposits: The role of slab contamination of asthenospheric melts in suprasubduction zone environments. Gondwana Research, v. 26, pp. 262-283.

Zhou, S., Mo, X.X., Mahoney, J.J., Zhang, S.Q., Guo, T.J., and Zhao, T.J., 2002, Geochronology and $\mathrm{Nd}$ and $\mathrm{Pb}$ isotope characteristics of gabbro dikes in the Luobusa ophiolite, Tibet. Chinese Science Bulletin, v. 47, pp. 143-146.

Zhou, S., 2002, Study on the Geochronology of pivotal regions of Gangdese magmatic and Yarlung Zangpo ophiolite belts, Tibet. Ph.D thesis, China University of Geosciences (Beijing) Beijing, pp. 75.

Zhu, D.C., Chung, S.L., Mo, X.X., Zhao, Z.D., Niu, Y.L., Song, B., and Yang, Y.H., 2009, The 132 Ma Comei-Bunbury large igneous province: remnants identified in present-day southeastern Tibet and southwestern Australia. Geology, v. 37, pp. 583-586.

Zhu, D.C., Mo, X.X., Wang, L.Q., Zhao, Z.D., and Liao, Z.L., 2008, Hotspotridge interaction for the evolution of Neo-Tethys: insights from the Late Jurassic-Early Cretaceous magmatism in southern Tibet. Acta Petrologica Sinica, v. 24, pp. 225-237.

Ziabrev, S.V., Aitchison, J.C., Abrajevitch, A., Badenzhu, Davis A.M., and Luo, H., 2003, Precise radiolarian age constraints on the timing of ophiolite generation and sedimentation in the Dazhuqu terrane, YarlungTsangpo suture zone, Tibet. Journal of the Society of London, v. 160, pp. 591-599.

Ziabrev, S.V., Aitchison, J.C., Badengzhu, Davis, A.M., Luo, H., and Malpas, J., 1999, Radiolarian biostratigraphy of supra-ophiolite sequences in the Xigaze area, Yarlung Tsangpo suture, southern Tibet (preliminary report). Radiolaria, v. 17, pp. 13-19. 